\title{
19. NEOGENE PLANKTONIC FORAMINIFERA FROM THE GULF OF ADEN AND THE WESTERN TROPICAL INDIAN OCEAN, DEEP SEA DRILLING PROJECT, LEG 24
}

\author{
Edith Vincent, Department of Geological Sciences, University of Southern California, Los Angeles, California \\ and \\ William E. Frerichs and Mary E. Heiman, Department of Geology, University of Wyoming, Laramie, Wyoming
}

\section{INTRODUCTION}

\section{General}

During Leg 24 of the Deep Sea Drilling Project, a total of eight sites was drilled in the western tropical Indian Ocean. Continuous coring and a high rate of recovery at most sites have provided an excellent basis for the study of low-latitude planktonic foraminiferal biostratigraphy in the Indian Ocean. This report should be considered preliminary, but the large amount of recovered material warrants much further study.

Neogene planktonic foraminifera were recovered at all sites, but there are major variations in abundance and preservation within and between the sites. Three distinct geographic areas were drilled; the Gulf of Aden, the northwestern Somali Basin, and the Mascarene Plateau/ Central Indian Ridge/Chagos-Laccadive Ridge complex area (Figure 1, Table 1).

The Gulf of Aden is a young and mobile region of intermediate depth bisected from east to west by Sheba Ridge, a seismically active zone which marks the spreading center (Matthews et al., 1967). Sheba Ridge is offset by several minor transform faults and near its eastern end by a linear north-northeast-trending cleft, the 5360 meter-deep Alula-Fartak Trench. Three sites were drilled in this region. Site 231 is located near the southern shore of the Gulf of Aden, $80 \mathrm{~km}$ off Somalia and Sites 232 and 233 were drilled on either side of the Alula-Fartak Trench. Site 232, on the western edge of the trench, lies northeast of the Sheba Ridge rift zone, whereas Site 233 on the eastern side is to the southwest of the rift. Site 231 reached igneous basement (approximately 13 m.y. old), whereas Sites 232 and 233 were terminated for technical reasons after reaching "acoustic basement," a massive quartzose sandstone at Site 232, and a diabase sill at Site 233. The sedimentary sequences, continuously cored, are similar at the three sites and consist of late Neogene hemipelagic nannofossil oozes which accumulated at a fast rate ( 44 to $75 \mathrm{~m} / \mathrm{m} . \mathrm{y}$. average). Despite the shallow water depth at the sites, a significant degree of dissolution of planktonic foraminifera was found throughout the sections.

The western Somali Basin is a magnetically quiet zone containing ponded sediments, $2-3 \mathrm{~km}$ thick, which appear similar in aspect on widely separated reflection profiles, with an acoustically transparent layer separating the upper and lower stratified (partly turbidite) sequence (Bunce et al., 1967). Two sites were drilled on either side of Chain
TABLE 1

Location of DSDP Leg 24 Sites

\begin{tabular}{llllll}
\hline & & & \multicolumn{3}{c}{ Neogene Section } \\
\cline { 3 - 6 } Site & Latitude & Longitude & Depth & $(\mathrm{m})$ & \multicolumn{1}{c}{ Cores } \\
\hline 231 & $11^{\circ} 53.41^{\prime} \mathrm{N}$ & $48^{\circ} 14.71^{\prime} \mathrm{E}$ & 2161 & 547 & $1-61$ \\
232 & $14^{\circ} 28.93^{\prime} \mathrm{N}$ & $51^{\circ} 54.87^{\prime} \mathrm{E}$ & 1758 & 434 & $1-19 ; 1 \mathrm{~A}-30 \mathrm{~A}$ \\
233 & $14^{\circ} 19.68^{\prime} \mathrm{N}$ & $52^{\circ} 08.11^{\prime} \mathrm{E}$ & 1860 & 234 & $1-19 ; 1 \mathrm{~A}-7 \mathrm{~A}$ \\
234 & $04^{\circ} 28.96^{\prime} \mathrm{N}$ & $51^{\circ} 13.48^{\prime} \mathrm{E}$ & 4738 & 161 & $1-9$ \\
235 & $03^{\circ} 14.06^{\prime} \mathrm{N}$ & $52^{\circ} 41.64^{\prime} \mathrm{E}$ & 5146 & 500 & $1-15$ \\
236 & $01^{\circ} 40.62^{\prime} \mathrm{S}$ & $57^{\circ} 38.85^{\prime} \mathrm{E}$ & 4504 & 177 & $1-19$ \\
237 & $07^{\circ} 04.99^{\prime} \mathrm{S}$ & $58^{\circ} 07.48^{\prime} \mathrm{E}$ & 1640 & 187 & $1-22$ \\
238 & $11^{\circ} 09.21^{\prime} \mathrm{S}$ & $70^{\circ} 31.56^{\prime} \mathrm{E}$ & 2844 & 405 & $1-43$ \\
\hline
\end{tabular}

Ridge in areas where deeper sediments onlap basement slopes beneath thinning younger layers and where it was hoped to reach and date basement. Site 234, west of Chain Ridge, was terminated because of technical difficulties after a penetration of only 247 meters. Site 235 , on the eastern flank of Chain Ridge, reached basement of Late Cretaceous age. The sedimentary sequences of both sites, which were discontinuously cored, show different sedimentary histories. Different source areas were revealed for the sediments of each site. An average accumulation rate of 5 $\mathrm{m} / \mathrm{m} . \mathrm{y}$. for Neogene sediments was calculated at Site 234, whereas at Site 235 middle Miocene through Pleistocene sediments accumulated at an average rate of $37 \mathrm{~m} / \mathrm{m} . \mathrm{y}$. Extensive dissolution of calcareous material and the presence of thick turbidite sequences at Site 235 make these sites unsuitable for foraminiferal biostratigraphic study.

Three sites were drilled in the central western Indian Ocean in the Mascarene Plateau/Central Indian Ridge/ Chagos-Laccadive Ridge complex area. Sites 236 and 237 are located west of the Carlsberg-Central Indian Ridge, and Site 238 is situated east of the Central Indian Ridge near the southern end of the Chagos-Laccadive Ridge. Neogene sequences of nannofossil oozes were recovered at all three locations. Continuous coring and good recovery at the three sites provided excellent material for Neogene planktonic foraminiferal biostratigraphic study, but dissolution was common in some parts of the sections, especially in the lower Miocene series. The latter are condensed and accumulated at an average rate about five times lower than the average accumulation rate of the middle Miocene to Quaternary sediments. 


\section{Methods}

A total of $118010-\mathrm{cc}$ samples from the eight sites was collected onboard Glomar Challenger for foraminiferal study with a sample interval of about 1.5 meters (each 9-m core was routinely cut into six sections; one sample was usually collected from each section). Samples were washed through a $63 \mu$ mesh sieve; dried samples were weighed before and after washing to obtain the percentage of sand-size components. Unconsolidated samples from the upper part of the holes disaggregated readily in water, but consolidated samples were prepared by treating them with a $15 \%$ solution of hydrogen peroxide. When this method was ineffective, thoroughly dried samples were immersed in kerosene and, after subsequent decantation, immersed in boiling water. The displacement of kerosene by water disaggregated the sediment.

All residues retained on the $63 \mu$ mesh sieve were examined for their foraminiferal content. Qualitative estimates of the abundance (reported as A: abundant, C: common, R: rare, and $\mathrm{B}$ : barren) and the preservation (reported as G: good, M: moderate, and P: poor) of foraminiferal faunas are given in the core forms for each site in Part 1 of this volume. After this preliminary examination, samples were selected for biostratigraphic study. The spacing of these selected samples depended on the nature and rate of accumulation of the sediments. Relatively fewer samples were examined from long uniform sequences, as well as from horizons where foraminifera were poorly preserved. Primary attention was paid to foraminiferal tests larger than $149 \mu$, although the smaller fraction was briefly examined. Most important planktonic species were investigated in the coarser fraction. Species abundance was visually estimated (reported as A: abundant, $>100$ specimens; C: common, $10-100$ specimens, and R: rare, $<10$ specimens) and is indicated in Tables 2 to 8 .

\section{Planktonic Foraminiferal Zonation}

The planktonic faunas encountered in sediments recovered on Leg 24 are representative of tropical conditions throughout the Neogene, and include warm-water species of worldwide distribution. It is therefore possible to use the well-known zonation systems developed in tropical areas for the subdivision of the Cenozoic (Bolli, 1957, 1966; Banner and Blow, 1965; Blow, 1969). Although the abbreviated "letter-number" system of Banner and Blow (1965) may be objectionable because of its inflexibility with respect to further subdivision, it was found convenient because of its brevity and is employed in this report.

Some zonal boundaries, however, were difficult to recognize. No attempt was made to differentiate Zones N23 and N22. The subspecies Sphaeroidinella dehiscens excavata is not sufficiently distinct to allow a separation of these two zones, and Globigerinella adamsi and G. calida were too rare to be stratigraphically significant. No attempt was made, as well, to differentiate Zones N20 and N19 which were combined. In addition to the taxonomic difficulty in identifying the index species Turborotalia pseudopima, this marker apparently evolved earlier (Brönnimann and Resig, 1971) than initially reported by Blow (1969). The extinction horizon of Globorotalia margaritae has been recog- nized as a datum contemporaneous with the N20/N19 boundary (Brönnimann and Resig, 1971; Berggren, 1973), but the rarity of this species in Leg 24 material precludes its use as a datum level here.

In several cases zonal boundaries proved difficult to recognize in this study because of: (1) the rarity of the nominate taxa, (2) the dissolution susceptibility (and resulting absence) of some zonal markers; and (3) taxonomic difficulties in the identification of some important markers. When the earliest and latest stratigraphic occurrences of a zonal index species were not believed to represent evolutionary events, zonal boundaries were tentatively drawn on the basis of the associated faunal assemblage.

\section{SITE 231}

\section{Geologic and Stratigraphic Setting}

Site 231 , in a water depth of 2160 meters, was drilled in the inner Gulf of Aden, south of Sheba Ridge and $80 \mathrm{~km}$ north of Somalia, in the so-called "Half Degree Square" (Laughton et al., 1970). The site is located beyond magnetic anomaly 5 , southwest of a small fracture zone which offsets Sheba Ridge.

Continuous coring with good recovery penetrated 567 meters of hemipelagic sediments, which represent an apparently uninterrupted sequence from Quaternary to middle Miocene directly above basement (approximately 13 m.y. old). The sediments consist of nannofossil oozes with intercalated sandy layers in the Pliocene and Pleistocene. The latter include commonly shallow-water-derived material. The average accumulation rate for the entire sedimentary sequence is approximately $44 \mathrm{~m} / \mathrm{m} . \mathrm{y}$. A higher rate for the Pleistocene and upper Pliocene sections (average of about 57 and $63 \mathrm{~m} / \mathrm{m} . y$. , respectively) reflects the input of displaced shallow-water sediments in these intervals.

\section{Abundance and Preservation of Foraminifera}

Moderately to poorly preserved foraminifera are the dominant component of the coarse fraction $(>63 \mu)$ throughout the sediments recovered at Site 231 except in the interval between Cores 47 and 57 (lowermost late Miocene and middle Miocene). Terrigenous components are common throughout the section and increase in relative percentage down the hole; they are abundant in some sandy horizons and dominate the coarse fraction between Cores 47 and 57. Pyrite is rare to common in Pliocene and Miocene sediments (below Core 9) and abundant in some horizons. Skeletal debris of pelecypods, gastropods, pteropods, and echinoderms are rare throughout the section. These are common in Pleistocene sandy horizons together with bryozoan and coral debris and shallow-water benthic foraminifera with abraded tests such as Amphistegina lessonii, Asterigerina sp., Ammonia gaimardii compressiuscula, and Elphidium spp. suggesting slumping from shelf areas.

Foraminiferal faunas exhibit signs of dissolution, especially in the lower Pliocene and Miocene, below Core 15. Planktonic faunas show an increasingly high degree of fragmentation below Core 8 , and in many horizons, the 


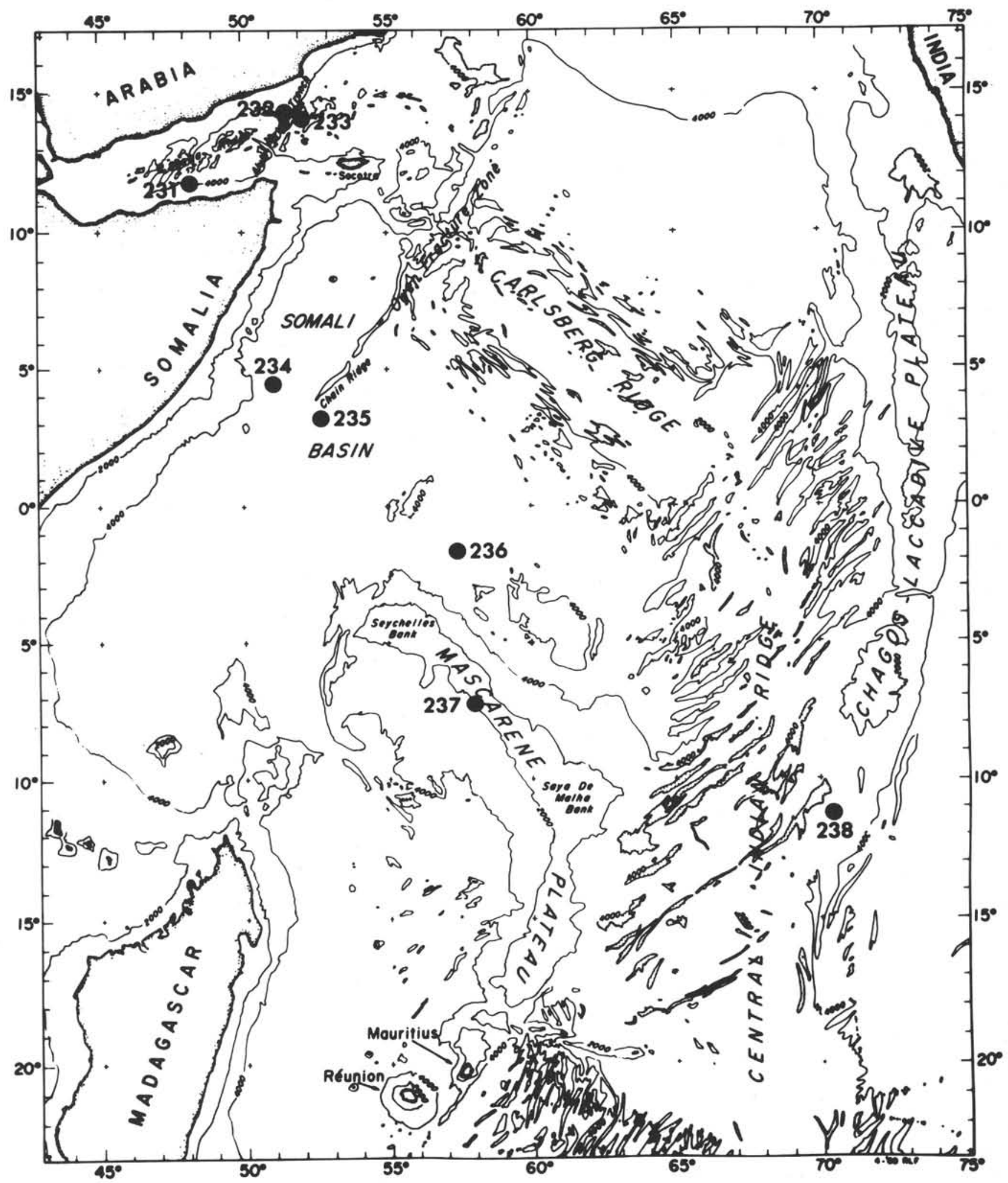

Figure 1. Location of DSDP Sites drilled on Leg 24. 
TABLE 2

Distribution of Selected Pleistocene and Pliocene Planktonic Foraminifera at Site 231

\begin{tabular}{|c|c|c|c|c|c|c|c|c|c|c|c|c|c|c|c|c|c|c|c|c|c|c|c|c|c|c|c|c|c|c|c|c|c|c|c|c|c|c|}
\hline 范 & 芩 & $\begin{array}{l}\text { Sample } \\
\text { (Interval } \\
\text { in } \mathrm{cm} \text { ) }\end{array}$ & 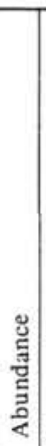 & 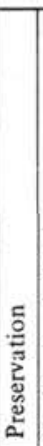 & 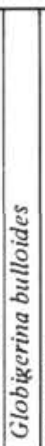 & 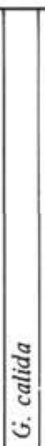 & 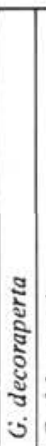 & 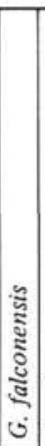 & 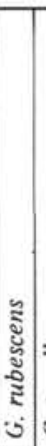 & : & 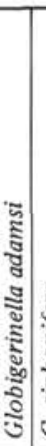 & 胥 & 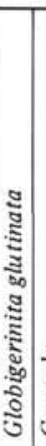 & : & 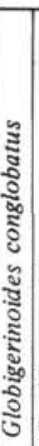 & 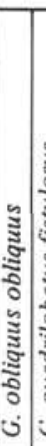 & 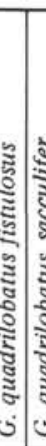 & & 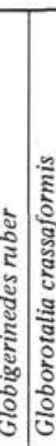 & 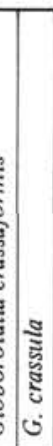 & 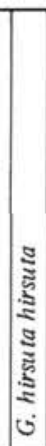 & 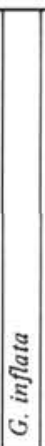 & 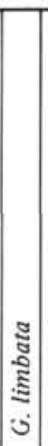 & $\mid \begin{array}{c}\vdots \\
\bar{z} \\
\vdots \\
\vdots \\
\vdots \\
ن \\
ن\end{array}$ & 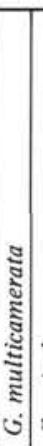 & : & 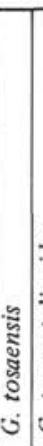 & 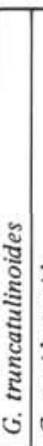 & 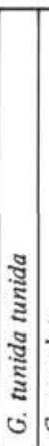 & & 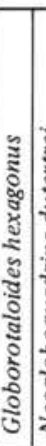 & 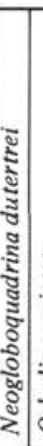 & 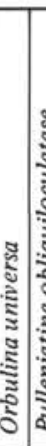 & 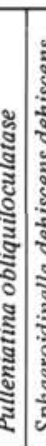 & 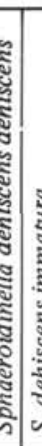 & 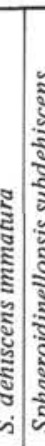 & 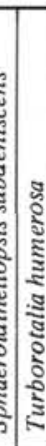 & 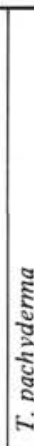 \\
\hline \multirow{20}{*}{ పే } & \multirow{20}{*}{$\begin{array}{l}\tilde{n} \\
\underset{z}{1} \\
\tilde{d} \\
\tilde{z}\end{array}$} & $1-1,130-132$ & $\mathrm{~A}$ & $\mathrm{M}$ & C & $\mathbf{R}$ & & & $\mathrm{R}$ & $\mathrm{R}$ & & $\mathrm{R}$ & $\mathrm{C}$ & & & & & $\mathrm{C}$ & A & $\mathrm{R}$ & & & & $\mathrm{A}$ & & $\mathrm{R}$ & & & & & $\mathrm{R}$ & $\mathrm{C}$ & \begin{tabular}{l|l}
$\mathrm{R}$ & $\mathrm{F}$
\end{tabular} & $R$ & & $\mathrm{R}$ & 2 & \\
\hline & & $2-2,63-65$ & $\mathrm{~A}$ & $\mathrm{M}$ & R & & & $\mathrm{R}$ & $\frac{N}{R}$ & & & R & C & & $\mathrm{R}$ & & & \begin{tabular}{l|l}
$C$ & $A$ \\
$R$ & $A$
\end{tabular} & \begin{tabular}{l|l}
$\mathrm{A}$ & $\mathrm{R}$ \\
$\mathrm{A}$ & $\mathrm{R}$ \\
\end{tabular} & $\begin{array}{l}\mathrm{N} \\
\mathrm{R}\end{array}$ & $\mathrm{R}$ & & & \begin{tabular}{|l|}
$\mathrm{A}$ \\
$\mathrm{A}$
\end{tabular} & & $\frac{N}{R}$ & & $\mathrm{R}$ & & & & \begin{tabular}{c|c} 
& \\
$C$ & 1
\end{tabular} & & $\overrightarrow{\mathrm{R}}$ & & & & $\mathrm{R}$ \\
\hline & & $3-1,73-75$ & $\mathrm{~A}$ & $\mathrm{G}$ & $\mathrm{R}$ & $\mathrm{R}$ & & $|\mathrm{R}|$ & $\frac{N}{R}$ & & $\mathrm{R}$ & C & $\mathrm{C}$ & & $\mathrm{R}$ & & & 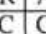 & \begin{tabular}{l|l}
$\mathrm{C}$ & $\mathrm{R}$ \\
\end{tabular} & $\mathrm{R}$ & $\mathrm{R}$ & & & \begin{tabular}{|l|l} 
C \\
\end{tabular} & & $\mathrm{R}$ & & C & & & & $\mathrm{C}$ & \begin{tabular}{l|l}
$\mathrm{R}$ & $\mathrm{F}$ \\
\end{tabular} & \begin{tabular}{l|l}
$\mathrm{R}$ & $\mathrm{F}$ \\
\end{tabular} & R & & & $\bar{R}$ \\
\hline & & $3-2,70-72$ & A & $\mathrm{M}$ & $\mathrm{R}$ & $\mathrm{R}$ & & $\mathrm{R}$ & $\mathrm{R}$ & & $\mathrm{R}$ & $\mathrm{R}$ & $\mathrm{C}$ & & $\mathrm{R}$ & & & $\begin{array}{ll}\mathrm{R} & \mathrm{C} \\
\end{array}$ & \begin{tabular}{l|l}
$\mathrm{C}$ & $\mathrm{C}$ \\
\end{tabular} & $\mathrm{R}$ & & & & C & & $\mathrm{R}$ & & & & & $\mathbf{R}$ & $\bar{R}$ & \begin{tabular}{l|l}
$\mathrm{R}$ & $\mathrm{F}$ \\
$\mathrm{B}$
\end{tabular} & \begin{tabular}{l|l}
$\mathrm{R}$ & $\mathrm{F}$ \\
\end{tabular} & $\mathrm{R}$ & & & \\
\hline & & $3-3,69-71$ & $\mathrm{~A}$ & $\mathrm{G}$ & $\mathrm{R}$ & $\mathrm{R}$ & & \begin{tabular}{|l|l}
$\mathrm{R}$ \\
\end{tabular} & $\mathrm{R}$ & \begin{tabular}{|l|l}
$\mathrm{R}$ \\
\end{tabular} & & $\mathrm{R}$ & $\mathrm{C}$ & & & & & C $A$ & \begin{tabular}{l|l}
$\mathrm{A}$ & $\mathrm{C}$ \\
\end{tabular} & & & & & C & & & & 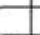 & & & $\mathrm{R}$ & $\mathrm{C}$ & \begin{tabular}{l|l}
$\mathrm{R}$ & $\mathrm{F}$ \\
\end{tabular} & \begin{tabular}{l|l}
$\mathrm{R}$ & $\mathrm{F}$ \\
\end{tabular} & R & & & $\mathrm{C}$ \\
\hline & & $3-4,49-51$ & $\mathrm{~A}$ & $\mathrm{M}$ & $\mathrm{R}$ & $\mathrm{R}$ & & $\mathrm{R}$ & $\mathrm{R}$ & \begin{tabular}{l|l}
$\mathrm{R}$ \\
\end{tabular} & & $\mathrm{R}$ & C & & $\mathrm{R}$ & & & C & \begin{tabular}{l|l}
$\mathrm{C}$ & $\mathrm{R}$ \\
\end{tabular} & $\begin{array}{ll}\mathrm{R} \\
\mathrm{R}\end{array}$ & & & & C & & $\mathrm{R}$ & & $\mathrm{R}$ & $\mathrm{R}$ & $R$ & & $\mathrm{R}$ & $\mathrm{R}$ & $\mathrm{R}$ & & & & $\overline{\mathrm{R}}$ \\
\hline & & $3-4,108-110$ & A & G & $\mathrm{R}$ & $\mathrm{R}$ & & & & $\mathrm{R}$ & & $\mathrm{R}$ & C & & & & & C & \begin{tabular}{l|l|l}
$\mathrm{A}$ & $\mathrm{R}$ \\
\end{tabular} & & & $\mathrm{R}$ & & C & & $\mathrm{R}$ & & $\mathrm{R}$ & & & $\mathrm{R}$ & $\mathrm{C}$ & $\mathrm{R}$ & $\mathrm{R}$ & & & & \\
\hline & & $4-1,70-72$ & A & $\mathrm{M}$ & $\mathrm{R}$ & $\mathrm{R}$ & & \begin{tabular}{|l|l}
$\mathrm{R}$ \\
\end{tabular} & $\mathrm{R}$ & $\mathrm{R}$ & & $\mathrm{R}$ & $\mathrm{C}$ & & & & & C 1 & C $\mathrm{R}$ & & & & & C & & $\mathrm{R}$ & & & $\mathrm{R}$ & R & $\mathrm{R}$ & C & $\mathrm{R}$ & $\mathrm{R}$ & & & & $\overline{\mathrm{R}}$ \\
\hline & & $4-2,53-55$ & $\mathrm{~A}$ & $\mathrm{M}$ & $\mathrm{R}$ & & & \begin{tabular}{|l|l|}
$\mathrm{R}$ \\
\end{tabular} & & & & $\mathrm{R}$ & C & $\mathrm{R}$ & & & & \begin{tabular}{l|l}
$\mathrm{R}$ & $\mathrm{C}$ \\
$\mathrm{R}$ & $\mathrm{c}$
\end{tabular} & \begin{tabular}{l|l|}
$\mathrm{C}$ & $\mathrm{R}$ \\
\end{tabular} & & & $\mathrm{R}$ & & $\mathrm{R}$ & & & & R & & & 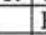 & $\mathrm{R}$ & $\mathrm{R}$ & $\mathrm{R}$ & & & & $\bar{B}$ \\
\hline & & $4-3,70-72$ & $\mathrm{~A}$ & $\mathrm{M}$ & $\mathrm{R}$ & & & $\mathrm{R}$ & $\mathrm{R}$ & & & R & $\mathrm{C}$ & & $\mathrm{R}$ & & & $\mathrm{R} A$ & \begin{tabular}{l|l}
$A$ & $C$ \\
\end{tabular} & & & & & \begin{tabular}{|l|l}
$\mathrm{R}$ \\
\end{tabular} & & $\mathrm{R}$ & & $\mathrm{R}$ & $\mathrm{R}$ & & $\mathrm{R}$ & $\mathrm{R}$ & \begin{tabular}{l|l}
$\mathrm{R}$ & $\mathrm{F}$ \\
$\mathrm{R}$
\end{tabular} & $\mathrm{R}$ & & & & \\
\hline & & $5-1,70-72$ & A & $\mathrm{M}$ & $\mathrm{R}$ & $\mathrm{R}$ & & & $\mathrm{R}$ & & & $\mathrm{R}$ & $\bar{R}$ & & $\mathrm{R}$ & & & $\mathrm{A} C \mathrm{C}$ & \begin{tabular}{l|l}
$\mathrm{C}$ & $\mathrm{R}$ \\
\end{tabular} & & & \begin{tabular}{|l|l|} 
R \\
\end{tabular} & & \begin{tabular}{l|l}
$\mathrm{R}$ \\
\end{tabular} & & & & R & $\mathrm{R}$ & & 1 & $\mathrm{R}$ & \begin{tabular}{l|l}
$\mathrm{R}$ & $\mathrm{F}$ \\
$\mathrm{R}$
\end{tabular} & $\mathrm{R}$ & & & & R \\
\hline & & $5-2,70-72$ & $\mathrm{~A}$ & $\mathrm{P}$ & $\mathrm{R}$ & & & $\mathrm{R}$ & & & & $\mathrm{R}$ & C & & & & & C 1 & \begin{tabular}{l|l}
$\mathrm{C}$ & $\mathrm{R}$ \\
\end{tabular} & & & $\mathrm{R}$ & & $\mathrm{R}$ & & $\mathrm{R}$ & & C & $\mathrm{R}$ & & & $\mathrm{R}$ & $\mathrm{R} \mathrm{H}$ & \begin{tabular}{l|l}
$\mathrm{R}$ & $\mathrm{I}$ \\
\end{tabular} & $\mathrm{R}$ & & & $\mathrm{R}$ \\
\hline & & $5-3,97-99$ & A & G & $\mathrm{R}$ & & & \begin{tabular}{l|l}
$\mathrm{R}$ \\
\end{tabular} & $\mathrm{R}$ & $\mathrm{R}$ & & $\mathrm{R}$ & $\mathrm{C}$ & & $\mathrm{R}$ & & & C $A$ & \begin{tabular}{l|l}
$A$ & C
\end{tabular} & & & & & $\mathrm{R}$ & & $\mathrm{R}$ & $\mathrm{R}$ & C & $\mathrm{R}$ & & $\mathrm{R}$ & C & $\mathrm{R}$ & C & & & & \\
\hline & & $5-4,70-72$ & A & $\mathrm{M}$ & $\mathrm{R}$ & $\mathrm{R}$ & & & & & & $\mathrm{R}$ & $\mathrm{C}$ & & $\mathrm{R}$ & & & C $A$ & $\begin{array}{ll}\mathrm{A} & \mathrm{R} \\
\end{array}$ & & & & & A & & $\mathrm{R}$ & $\mathrm{R}$ & C & $\mathrm{R}$ & & $\mathrm{R}$ & C & $\mathrm{RC}$ & C & & & & \\
\hline & & $5-5,68-70$ & A & $M$ & C & & & & $\mathrm{R}$ & $\mathrm{R}$ & & $\mathrm{R}$ & C & & & & & $\mathrm{R} A$ & $\begin{array}{ll}A & R \\
\end{array}$ & & & C & & C & & $\mathrm{R}$ & & $\mathrm{R}$ & & & & $\mathrm{R}$ & \begin{tabular}{l|l}
$\mathrm{R}$ & $\mathrm{F}$ \\
\end{tabular} & \begin{tabular}{l|l}
$\mathrm{R}$ & $\mathrm{I}$ \\
\end{tabular} & $\mathrm{R}$ & & & P \\
\hline & & $5-6,63-65$ & A & M & R & $\mathrm{R}$ & & & & $\mathrm{R}$ & & c & C & & $\mathrm{R}$ & & & $\mathrm{R}$ & $\mathrm{A} / \mathrm{R}$ & & & & & C & & & $\mathrm{R}$ & $\mathrm{R}$ & & & & $\mathrm{R}$ & \begin{tabular}{l|l}
$\mathrm{R}$ & $\mathrm{B}$ \\
\end{tabular} & $\mathrm{R}$ & & & & $\underline{B}$ \\
\hline & & $6-1,70-72$ & A & $\mathrm{M}$ & $\mathrm{R}$ & & & \begin{tabular}{|l|l|}
$\mathrm{R}$ \\
\end{tabular} & & $\mathrm{R}$ & & $\mathrm{R}$ & C & & $\mathrm{R}$ & & & C & C & & & & & C & & $\mathrm{R}$ & $\mathrm{R}$ & $\mathrm{R}$ & & & & $\mathrm{R}$ & $\begin{array}{ll}\mathrm{R} \\
\mathrm{R}\end{array}$ & $\mathrm{R}$ & & & & \\
\hline & & $6-3,69-71$ & A & $\mathrm{P}$ & $\mathrm{R}$ & $\mathrm{R}$ & & & & $\mathrm{R}$ & & R & R & & $\mathrm{R}$ & & $\begin{array}{ll}\mathrm{R} & A \\
\end{array}$ & \begin{tabular}{l|l}
$\mathrm{A}$ & $\mathrm{C}$ \\
$\mathrm{C}$
\end{tabular} & $\mathrm{C}$ & $\mathrm{R}$ & & & & A & & $\mathrm{R}$ & $\mathrm{C}$ & $\mathrm{R}$ & & & $\begin{array}{ll}\mathrm{R} & 1 \\
\end{array}$ & $\mathrm{R}$ & $\mathrm{R} C$ & C & & & & F \\
\hline & & $6-4,70-72$ & A & G & C & & & \begin{tabular}{|l|l}
$\mathrm{R}$ \\
\end{tabular} & & $\mathrm{R}$ & & C & $\mathrm{C}$ & & $\mathrm{R}$ & & $\mathrm{R} / A$ & \begin{tabular}{l|l}
$\mathrm{A}$ & $\mathrm{C}$ \\
$\mathrm{n}$
\end{tabular} & $\mathrm{C}$ & & & & & C & & $\mathrm{R}$ & & $\mathrm{R}$ & & & & C & \begin{tabular}{l|l}
$C \mathrm{~F}$ \\
$\mathrm{C}$
\end{tabular} & $\mathrm{R}$ & & & & $\bar{B}$ \\
\hline & & $6-5,70-72$ & $\mathrm{~A}$ & $\mathrm{M}$ & & & & & & & & $\mathrm{R}$ & C & & & & & & $\mathrm{A}$ & $\mathrm{R}$ & & \begin{tabular}{|l|}
$R$ \\
\end{tabular} & & C & & $\mathrm{R}$ & $\mathrm{R}$ & $\mathrm{C}$ & & & $\mathrm{R}$ & $\mathrm{R}$ & $\mathrm{R}$ & $\mathrm{R}$ & & & & \\
\hline \multirow{14}{*}{ ت } & \multirow{14}{*}{$\overline{\tilde{z}}$} & $6-6,7$ & A & $M$ & & & $\mathrm{R}$ & & $\mathrm{R}$ & & & $\mathrm{R}$ & A & & & $\mathrm{R}$ & & $\mathrm{A}$. & $\mathrm{A}$ & & & & & C & & $\mathrm{R}$ & $\mathrm{R}$ & & & & $\mathrm{R}$ & C & \begin{tabular}{l|l}
$\mathrm{R}$ & $\mathrm{F}$ \\
\end{tabular} & $\mathrm{R}$ & & P & $\mathrm{R}$ & \\
\hline & & $7-1,90-92$ & $\mathrm{R}$ & M & $\mathrm{R}$ & & & & & & & $\mathrm{R}$ & $\mathrm{C}$ & & $\mathrm{R}$ & & & A & C & & & $\mathrm{R}$ & & $\mathrm{C}$ & & $\mathrm{R}$ & & & $\mathrm{R}$ & & & $\mathrm{R}$ & \begin{tabular}{l|l}
$\mathrm{R}$ & $\mathrm{F}$ \\
\end{tabular} & $\vec{R}$ & & & & $\mathrm{~F}$ \\
\hline & & $7-3,70-72$ & A & $\mathrm{G}$ & $\mathrm{R}$ & & & \begin{tabular}{|l|l|}
$\mathrm{R}$ \\
\end{tabular} & & & & $\mathrm{R}$ & $\mathrm{R}$ & & $\mathrm{R}$ & & & $\mathrm{A}$ C & C & & & & & R & & $\mathrm{R}$ & \begin{tabular}{l|l}
$R$ \\
\end{tabular} & & & & $\mathrm{R}$ & $\mathrm{C}$ & \begin{tabular}{l|l}
$\mathrm{C}$ & $\mathrm{C}$ \\
\end{tabular} & \begin{tabular}{l|l} 
C \\
\end{tabular} & $\bar{C}$ & $\begin{array}{ll}\mathrm{R} & \mathrm{B} \\
\end{array}$ & 2 & F \\
\hline & & $8-5,70-72$ & A & $\mathrm{M}$ & $\mathrm{R}$ & & & & $\mathrm{R}$ & & & $\mathrm{R}$ & C & $\mathrm{R}$ & & & & $\mathrm{C} C$ & $\bar{c}$ & & & & & A & & \begin{tabular}{l|l} 
\\
$\mathrm{R}$
\end{tabular} & $\mathrm{R}$ & $\mathrm{R}$ & & & $\mathrm{R}$ & $\bar{R}$ & \begin{tabular}{l|l}
$\mathrm{R}$ & $\mathrm{H}$ \\
\end{tabular} & $\mathrm{R}$ & & & & c \\
\hline & & $9-3,70-72$ & A & $\mathrm{M}$ & $\mathrm{R}$ & & & \begin{tabular}{|l|}
$\mathrm{R}$ \\
\end{tabular} & $\mathrm{R}$ & & & $\mathrm{R}$ & $\mathrm{C}$ & & $\mathrm{R}$ & & & $\mathrm{C}$ & A & & & & & R & & $\mathrm{R}$ & $\mathrm{C}$ & & R & & $\mathrm{R}$ & $\bar{R}$ & \begin{tabular}{l|l}
$\mathrm{R}$ & $\mathrm{F}$ \\
\end{tabular} & $\mathrm{R}$ & & & & c \\
\hline & & $9-4,70-72$ & $\mathrm{~A}$ & $\mathrm{M}$ & $\mathrm{R}$ & & & & & & & C & $\bar{R}$ & & & & & $\mathrm{C} A$ & A & & & & & C & & \begin{tabular}{l|l}
$\mathrm{R}$ & $\mathrm{C}$ \\
\end{tabular} & $\mathrm{C}$ & & & & & $\mathrm{R}$ & $\mathrm{R}$ & & & & & $\bar{R}$ \\
\hline & & $9-5,70-72$ & A & M & $\mathrm{R}$ & & & & & & & $\mathrm{R}$ & $\mathrm{R}$ & & & & & \begin{tabular}{l|l} 
R & $A$ \\
\end{tabular} & $\mathrm{~A}$ & & & & & \begin{tabular}{|l|}
$\mathrm{R}$ \\
\end{tabular} & & $\bar{R}$ & $\mathrm{R}$ & & & & & $\mathrm{C}$ & $\mathrm{R}$ & $\bar{R}$ & & $\mathrm{R}$ & & R \\
\hline & & $9-6,70-72$ & A & $\mathrm{P}$ & $\mathrm{R}$ & & $\mathrm{R}$ & & $\mathrm{R}$ & & & & $\mathrm{C}$ & & $\mathrm{R}$ & \begin{tabular}{l|l}
$\mathrm{R}$ & $\mathrm{I}$
\end{tabular} & $\mathrm{R} / \mathrm{C}$ & C & $\mathrm{A}$ & & & & & \begin{tabular}{|l|}
$\mathrm{R}$ \\
\end{tabular} & & & $\mathrm{R}$ & & & & & C & \begin{tabular}{l|l}
$\mathbf{R}$ & $\mathrm{H}$ \\
\end{tabular} & \begin{tabular}{l|l} 
R & 1 \\
\end{tabular} & R & & & \\
\hline & & $10-2,70-72$ & A & $\mathbf{P}$ & $\mathrm{R}$ & & & & $\mathrm{R}$ & & & $\mathrm{R}$ & C & & $\mathrm{R}$ & & & $\begin{array}{c:c} & \text { C } \\
\end{array}$ & C & & & & & $\mathrm{C}$ & $R$ & \begin{tabular}{l|l}
$R$ & 1 \\
\end{tabular} & $\mathrm{R}$ & & & & & R & \begin{tabular}{l|l}
$\mathrm{R}$ & $\mathrm{C}$ \\
\end{tabular} & \begin{tabular}{l|l} 
C & 1
\end{tabular} & \begin{tabular}{l|l} 
R & $F$ \\
\end{tabular} & R & & \\
\hline & & $11-3,70-72$ & $\mathrm{C}$ & P & $\mathrm{R}$ & & & & $\mathrm{R}$ & & & $\mathrm{R}$ & C & & & & c & C & $\bar{c}$ & & & & & \begin{tabular}{|l|}
$\mathrm{R}$ \\
\end{tabular} & & R & & & & & $\mathrm{R}$ & $\overline{\mathrm{R}}$ & \begin{tabular}{l|l}
$\mathbf{R}$ & $\mathbf{C}$ \\
\end{tabular} & C & & F & 2 & \\
\hline & & $12-1,70-72$ & A & M & $\mathrm{R}$ & & & & & & & C & C & & & & & $\begin{array}{l}\mathrm{A} \\
\mathrm{A}\end{array}$ & $\mathrm{A}$ & & & & & $\mathrm{R}$ & & & $\mathrm{R}$ & $\mathrm{R}$ & & \begin{tabular}{l|l}
$\mathrm{R}$ \\
\end{tabular} & $\bar{R}$ & $\mathrm{C}$ & 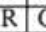 & C & & & & R \\
\hline & & $13-3,69-71$ & A & $\mathrm{P}$ & $\mathrm{R}$ & & & & $\mathrm{R}$ & & & R & $\mathrm{C}$ & & & & & C & C & & & & $\mathrm{R}$ & C & & $\mathrm{R}$ & & & & & & $\bar{R}$ & \begin{tabular}{l|l}
$\mathrm{R}$ & $\mathrm{C}$ \\
\end{tabular} & $\bar{C}$ & & $\mathrm{R}$ & $\bar{R}$ & \\
\hline & & $13-4,70-72$ & A & \begin{tabular}{|l|}
$\mathrm{P}$ \\
\end{tabular} & & & & \begin{tabular}{|l|}
$\mathrm{R}$ \\
\end{tabular} & & & & $\mathrm{R}$ & \begin{tabular}{c|c} 
C \\
\end{tabular} & \begin{tabular}{l|l}
$\mathrm{R}$ & $\mathrm{I}$ \\
\end{tabular} & $\mathrm{R}$ & & & \begin{tabular}{l|l}
$\mathrm{R}$ & $\mathrm{C}$ \\
\end{tabular} & C & & & & & \begin{tabular}{|l|}
$\mathrm{R}$ \\
\end{tabular} & & & & & & & \begin{tabular}{l|l}
$\mathrm{R}$ & $\mathrm{I}$ \\
\end{tabular} & $\bar{R}$ & \begin{tabular}{l|l}
$\mathrm{R}$ & $\mathrm{F}$ \\
\end{tabular} & $\mathrm{R}$ & & & & \\
\hline & & \begin{tabular}{|l}
$14-1,68-70$ \\
\end{tabular} & $\mathrm{~A}$ & $\mathrm{P}$ & & & $\mathrm{R}$ & & & & & C & C & & & \begin{tabular}{l|l}
$\mathrm{R}$ & $\mathrm{I}$ \\
$\mathrm{n}$
\end{tabular} & $\begin{array}{ll}\mathrm{R} & \mathrm{C} \\
\mathrm{R}\end{array}$ & \begin{tabular}{l|l}
$\mathrm{N}$ & $\mathrm{C}$ \\
$\mathrm{C}$ & $\mathrm{C}$
\end{tabular} & c & & & & C & C & & & $R$ & & $\mathrm{R}$ & R & & R & $\bar{R}$ & $\overrightarrow{\mathrm{C}}$ & & & $\bar{R}$ & \\
\hline
\end{tabular}

planktonic species are predominantly forms with robust solution-resistant tests. Dissolution of planktonic foraminifera is also reflected by the high relative frequency of benthic species, which are more resistant to solution and which sometimes dominate the assemblages. Planktonic foraminifera are dominant in Cores 1 to 25 (Pleistocene and Pliocene), they constitute from 80 to over 99 percent of the total foraminiferal fauna in Cores 1 to 15 , and 50 to 80 percent of the fauna in Cores 16 to 25. Below Core 25, relative proportions of planktonics and benthics are variable. Planktonic species make up 30 to 80 percent of the fauna, and are very rare in some intervals (especially in Core 47 and in the interval between Cores 50 and 57).

The significant degree of solution at such a shallow depth is puzzling and might be related to several factors such as the occurrence of upwelling bringing cold aggressive water close to the surface in the Gulf of Aden, or to reducing conditions within the sediments reflected by the abundance of pyrite.

\section{Planktonic Foraminiferal Zonation}

The interval Core 1 to Core 6, Section 5 is assigned to the Quaternary (Zones N.23 and N.22) as indicated by the common presence of Globorotalia truncatulinoides. Specimens of pink-colored Globigerina rubescens occur commonly above the lowest occurrence of Globigerinella adamsi in the interval Core 1 to Core 3, Section 2, rarely in the interval between Core 3, Section 3 to Core 5, Section 3 , and they were not found below.

The N.22/N.21 zonal limit (Pleistocene/Pliocene boundary) is placed in Core 6 , Section 5 , at the base of the common occurrence of $G$. truncatulinoides. The exact level of the evolutionary appearance of this species from its direct ancestor Globorotalia tosaensis cannot be easily determined. Specimens intermediate between $G$. truncatulinoides and $G$. tosaensis (with a rounded edge but with an imperforate band) occur occasionally throughout the interval between Core 3, Section 4 and Core 12, Section 1. The highest occurrence of G. tosaensis (specimens with a 
perforate rounded edge) is in Core 5, Section 2. The latter species occurs rarely in the interval between Core 5, Section 2 and Core 6, Section 1, commonly between Core 6, Section 3 and Core 9, Section 4, and rarely below. The base of the common occurrence of G. truncatulinoides (in Core 6 , Section 5) approximates the highest occurrence of Globigerinoides quadilobatus fistulosus, the lowest appearance of Globigerina tenella (in Core 6, Section 4), and the highest occurrence of Globigerinoides obliquus extremus (in Core 6, Section 6).

An interval with dextrally coiled Globorotalia tumida tumida was found between Core 9, Section 4 and Core 10, CC. A horizon containing Globoquadrina $s p$. A (a new species to be described in a subsequent paper) occurs in Sample 12, CC, slightly above the highest occurrence of Globorotalia limbata and Turborotalia humerosa in Core 13, Section 3. The N.21/N.20-N.19 zonal limit is drawn between Cores 19 and 20 at the lowest occurrence of $G$. tosaensis. The N.19/N.18 boundary is placed between Cores 27 and 28, at the lowest occurrence of Sphaeroidinella dehiscens, although the scarcity of this species at this site makes it an unreliable biostratigraphic indicator for the Gulf of Aden. The N.18/N.17 limit (Pliocene/Miocene boundary), based on the lowest occurrence of Globorotalia tumida tumida, lies between Cores 28 and 29 .

Cores 30 to 46 are assigned to the late Miocene Zones $\mathrm{N} .17$ to N.15. The N.17/N.16 boundary is placed at the base of Globorotalia tumida plesiotumida, between Cores 34 and 35, and Zones N.16 and N.15 were not differentiated. The lowest occurrence of Turborotalia acostaensis lies in Core 43, but Globorotalia merotumida ranges lower; as low as Core 46, Section 5. Preservation of planktonic foraminifera is inadequate between Core 46 , Section 5 and Core 48 , Section 3 , and no biostratigraphic data was obtained from this interval.

The lower part of the section from Core 48 , Section 3 to the bottom of the hole contains common Turborotalia siakensis and is assigned to middle Miocene Zones N.14 to N.12. In this interval, many horizons did not yield biostratigraphically valuable data because of the poor preservation of planktonic foraminifera, especially in Core 49 and between Cores 51 and 57. The N.14/N.13 boundary was not determined. Rare forms referable to Globigerina nepenthes, which is known to define the base of N.14, occurs as far down as Core 59. Section 2, however, forms known to become extinct within N.13 are present higher in the section. The highest occurrences of Globigerinoides subquadratus and Turborotalia mayeri lie, respectively, in Core 50. Section 6 and Core 58, Section 2. The N,13/N.12 boundary is placed at the lowest occurrence of Sphaeroidinellopsis subdehiscens in Core 61, Section 2, which is also the level of highest appearance of Globorotalia fohsi fohsi and Globorotalia peripheroacuta. The lowest sample, just above the basalt and below the altered volcanic ash (Sample $62-1,85-90 \mathrm{~cm}$ ) contains a rich but altered planktonic fauna including Globorotalia fohsi fohsi, G. fohsi lobata, G. fohsi robusta, Globorotalia peripheroacuta, Globorotalia peripheroronda, and Globorotalia praefohsi. This assemblage belongs to the faunal Zone N12 and is 12.5 to 12.8 m.y. old according to the Berggren and Van Couvering (1974) time scale.

\section{SITE 232}

\section{Geologic and Stratigraphic Setting}

Two holes were drilled at Site 232 in a water depth of 1758 meters. This site is located at the eastern end of the Gulf of Aden on the northwest flank of the Alula-Fartak Trench above a basement of magnetic age about 10 m.y. Ramsay and Funnell (1969), who studied the foraminiferal biostratigraphy of sediments dredged from the sides of the trench, reported that this structure has been the site of sedimentation since at least the late middle Miocene (late N16).

The sedimentary section continuously cored consists of 434 meters of nannofossil oozes with occasional sandy layers and a few intercalations of quartz siltstone and sandstone and represents an apparently uninterrupted sequence from Quaternary to late Miocene. There is a gradual decrease in the average accumulation rate throughout the section from about $89 \mathrm{~m} / \mathrm{m} . \mathrm{y}$. in the late Miocene to about $44 \mathrm{~m} / \mathrm{m} . \mathrm{y}$. in the Pleistocene. The average accumulation rate for Pleistocene and Pliocene sediments is approximately $55 \mathrm{~m} / \mathrm{m} . \mathrm{y}$. The lower 37 meters of the section, a massive quartzose sandstone ("acoustic basement") which may represent a fault or slide block, could not be dated because of poor recovery and lack of datable fossils; however, the bottom of the hole, at 434 meters, is judged to be approximately 6.7 m.y. old (upper part of the late Miocene) on the basis of sedimentation rate estimates.

\section{Abundance and Preservation of Foraminifera}

Well-preserved to moderately preserved foraminifera are the dominant component of the coarse fraction $(>63 \mu)$ in the upper 40 meters of the section (Cores 1 to 5). Below 40 meters, foraminifera are less abundant and are moderately to poorly preserved while radiolarians and terrigenous components, small subangular quartz grains and mica flakes, become common. No foraminifera could be extracted from the Miocene lithified quartzose silstone and sandstone and only two benthic foraminifera, neither identifiable, were observed in thin sections from these units.

Planktonic foraminifera dominate the foraminiferal assemblages in Cores 1 through 5 in which they commonly comprise more than 90 percent of the total foraminiferal population. In Cores 6 to $1 \mathrm{~A}$ they make up only 30 to 50 percent of the foraminiferal assemblages, whereas in this interval benthics are dominant. In the lower part of the section, below Core 1A, planktonic foraminifera constitute 50 to 80 percent of the population. The downward decrease in relative abundance of planktonic foraminifera, appears to be related to calcium carbonate solution. This is also evidenced by the poorer preservation of planktonic foraminifera, which present a significant degree of fragmentation and a higher relative proportion of radiolarians below Core 5 .

\section{Planktonic Foraminiferal Zonation}

The interval from Core 1 to Core 5, Section 4, is assigned to the Quaternary (Zones N.23-N.22) based on the common presence of Globorotalia truncatulinoides. As at Site 231, specimens of pink Globigerina rubescens occur 
TABLE 3

Distribution of Selected Miocene Planktonic Foraminifera at Site 231

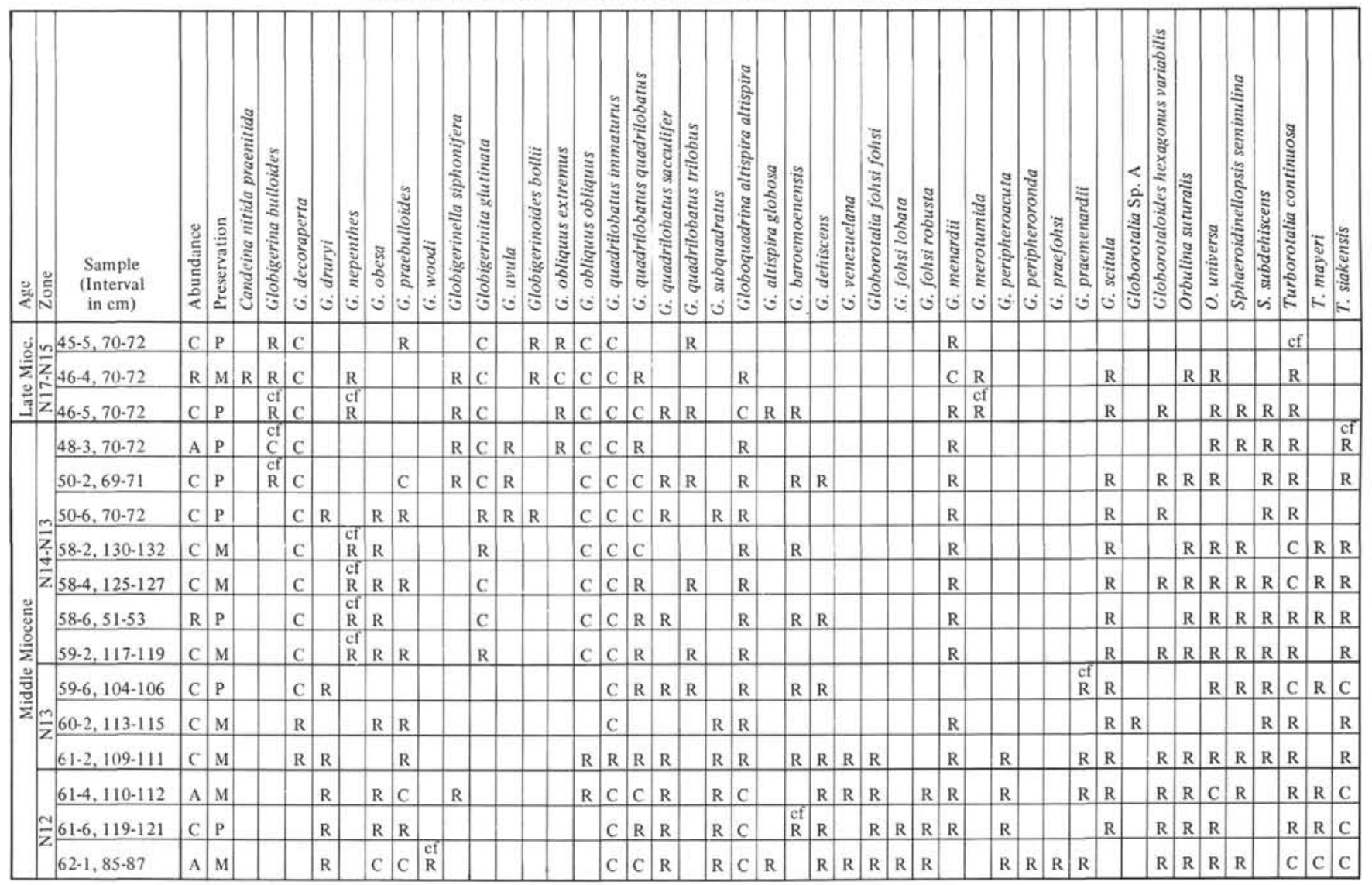

commonly in the upper part of the section (Core 1 and Core 2, Section 4) and were not found in lower levels. The N.22/N.21 boundary was placed, as at Site 231, at the base of the common occurrence of $G$. truncatulinoides, in Core 5 , Section 4. However, rare specimens of this species were found below this level, between Cores 7 and 11 . It is not easy to determine whether this presence is due to downhole contamination or if the initial evolutionary appearance of $G$. truncatulinoides occurs lower in the section. Only rare occurrences of Globorotalia tosaensis, the direct ancestor of $G$. truncatulinoides, were found in the interval between Core 6, Section 2 and 12, CC, and the transition between the two species could not be observed. As at Site 231, the base of the common occurrence of $G$. truncatulinoides coincides with the lowest appearance of Globigerina tenella; however, none of the two species Globigerinoides obliquus s.l. and Globigerinoides quadrilobatus fistulosus were found near this level.

A horizon with dextrally coiled Globorotalia tumida tumida was observed in Core 6, Section 2, and the presence of Globoquadrina sp. A was found in Core 9, Section 2, at the same level as the highest occurrence of Globorotalia limbata. This succession of events in the upper part of Zone N.21 correlates with the same events at Site 231. The N.21/N.20-N.19 boundary is not conclusively determined due to the rarity of the index species, $G$. tosaensis. It is, however, tentatively placed at the highest occurrence of
Sphaeroidinellopsis, between Cores 15 and 16, a level slightly below the top of Globoquadrina altispira s.s.

A horizon, including common Globorotalia tumida flexuosa, located in the lower part of Core 19 and in Core $2 \mathrm{~A}$ and Core $3 \mathrm{~A}$, Section 2 allows the correlation between Holes 232 and 232A. Core 19 corresponds to Core 2A, a correlation in agreement with the subbottom depths of these cores. Very rare occurrences of Globorotalia margaritae (a species known to become extinct elsewhere within N.19) were observed in Core $4 \mathrm{~A}$, Section 4 . The base of Zone N.19 cannot be conclusively determined because the index marker, Sphaeroidinella dehiscens, first appears higher in this section than its known evolutionary appearance, as reported elsewhere. The N.19/N.18 boundary was tentatively placed at the highest occurrence of forms referable to Globorotalia tumida plesiotumida, between Cores $9 \mathrm{~A}$ and $10 \mathrm{~A}$.

The N.18/N.17 boundary was not identified because forms intermediate between $G$. tumida tumida and $G$. tumida plesiotumida were commonly found throughout the interval between Core 10A, Section 1 and Core 23A, Section 2. Specimens attributable to G. tumida tumida occur as low in the section as Core $23 \mathrm{~A}$, Section 2, but this level is probably too low for the base of Zone N.18 as it lies below the lowest occurrence of Pulleniatina spp. and is lower than the Miocene/Pliocene boundary defined by nannofossils and radiolarian zonations. 
SITE 233

\section{Geologic and Stratigraphic Setting}

Site 233 was drilled in about 1860 meters of water on the back side of the eastern flank of the Alula-Fartak Trench close to magnetic anomaly 3 . Two holes were continuously cored at the same location. Drilling was terminated after encountering the acoustic basement, a diabase sill perhaps 8 to 37 meters thick. The 234 meters of sedimentary section above the diabase represent an apparently continuous sequence from Quaternary to late Pliocene of hemipelagic nannofossil oozes, which accumulated at an average rate of about $45 \mathrm{~m} / \mathrm{m} . \mathrm{y}$. during the Pleistocene and $117 \mathrm{~m} / \mathrm{m} . \mathrm{y}$. during the late Pliocene. The sediments just above the diabase have an approximate age of 3 m.y. (lowermost late Pliocene).

\section{Abundance and Preservation of Foraminifera}

Foraminifera are the dominant component of the coarse fraction $(>63 \mu)$ in Cores 1 to 6 in which they are well to moderately preserved. They are common and moderately to poorly preserved in Cores 7 to 11 . They are rare and poorly preserved throughout the remainder of the section while small subangular quartz grains and radiolarians become the dominant components of the coarse fraction. The major factor responsible for the marked downward decrease in the abundance of foraminifera appears to be solution of calcium carbonate as evidenced by (1) the poorer preservation with increasing depth, (2) an increase in the relative frequency of benthic foraminifera with increasing depth, and (3) an increase in the relative frequency of radiolarians with increasing depths. Planktonic foraminifera comprise usually more than 80 percent of the total foraminiferal fauna in the upper 52 meters (Cores 1 to 6) and constitute only 30 to 70 percent of the fauna in the remainder of the section.

\section{Planktonic Foraminiferal Zonation}

The interval Core 1 to Core 3, Section 2 is assigned to the Quaternary (N.23-N.22), as indicated by the presence of Globorotalia truncatulinoides, and the remainder of the section, which contains Globorotalia tosaensis only, is assigned to the late Pliocene Zone N.21. Several foraminiferal events correlate with similar events in the two other sites of the Gulf of Aden. The lowest occurrence of Globigerina tenella was found in Core 3, Section 2 at the same level as the base of Globorotalia truncatulinoides; a horizon with dextrally coiled Globorotalia tumida tumida was observed in Core 5, CC; the highest occurrence of Globorotalia limbata lies in Core 8, Section 3; and the highest appearance of Globoquadrina altispira s.s. occurs in Core $2 \mathrm{~A}$, Section 2 (the occurrence of this species in Core 8 , Section 3 is probably due to displacement).

TABLE 4

Distribution of Selected Neogene Planktonic Foraminifera at Site 233

\begin{tabular}{|c|c|c|c|c|c|c|c|c|c|c|c|c|c|c|c|c|c|c|c|c|c|c|c|c|c|c|c|c|c|c|c|c|c|c|c|c|}
\hline 选 & స్ & $\begin{array}{c}\text { Sample } \\
\text { (Interval } \\
\text { in } \mathrm{cm} \text { ) }\end{array}$ & 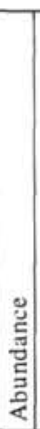 & 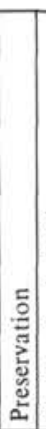 & 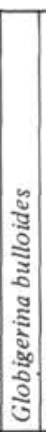 & 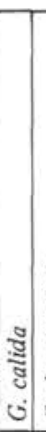 & 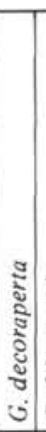 & $\begin{array}{l}\vdots \\
\vdots \\
\vdots \\
\vdots \\
0 \\
\vdots \\
0 \\
0\end{array}$ & 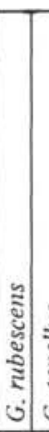 & 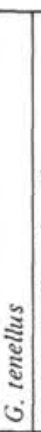 & 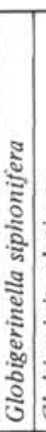 & 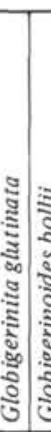 & 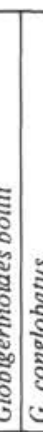 & 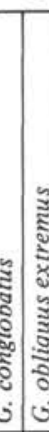 & 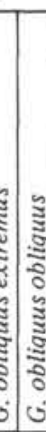 & 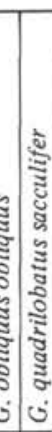 & 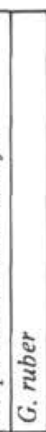 & 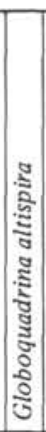 & 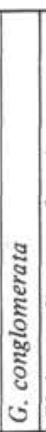 & 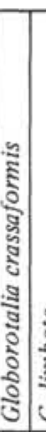 & 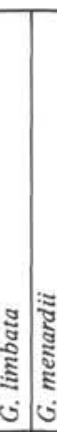 & 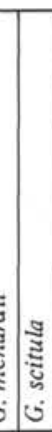 & 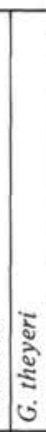 & 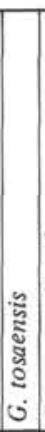 & 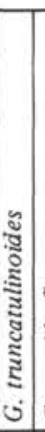 & 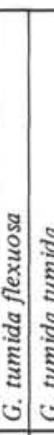 & 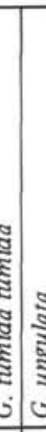 & 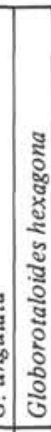 & 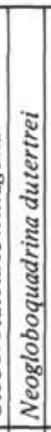 & 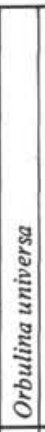 & 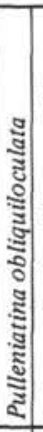 & 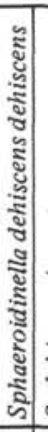 & 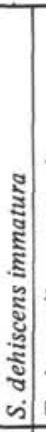 & 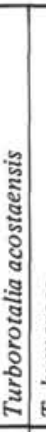 & & 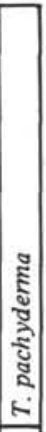 \\
\hline \multirow{3}{*}{$\frac{5}{\frac{2}{2}}$} & \multirow{3}{*}{ त̇ं } & 2 & A & (i) & A & C. & & c: & A & C: & C & A & & & & A & $A$ & & C & C & A & $\begin{array}{lll}4 & C \\
4\end{array}$ & C & & & & & C & $\mathrm{A}$ & $\mathrm{A}$ & A & & & & C & \\
\hline & & $2-2,60-62$ & A & G & $\mathrm{A}$ & & & $\mathrm{A}$ & $\mathrm{A}$ & $\mathrm{C}$ & C & $\mathrm{A}$ & & & & $\frac{\mathrm{A}}{\mathrm{A}}$ & A & & $\begin{array}{l}\mathrm{C} \\
\mathrm{C}\end{array}$ & c & $\bar{A}$ & $\begin{array}{lll}4 \\
A\end{array}$ & C & & & $c$ & C & $\mathrm{C}$ & $|\mathrm{A}|$ & $\mathrm{A} \mid$ & $\mathrm{A}$ & & & & $\begin{array}{l}\mathrm{R} \\
\mathrm{R}\end{array}$ & A \\
\hline & & $3-2,120-122$ & $\mathrm{~A}$ & $\mathrm{G}$ & A & & & A & A & C & $\mathrm{C}$ & $\mathrm{A}$ & & & & A & $\mathrm{A}$ & & $\begin{array}{ll} \\
\end{array}$ & $\mathrm{c}$ & A & $\begin{array}{ll}A \\
A\end{array}$ & $\mathrm{C}$ & C & $\mathrm{A}$ & & & R & A & A & A & & & & R & C \\
\hline \multirow{23}{*}{ 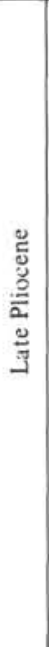 } & \multirow{23}{*}{$\vec{z}$} & $4-2,98-100$ & $\mathrm{C}$ & G & \begin{tabular}{|l|l|}
$R$ \\
\end{tabular} & & & $\mathrm{R}$ & & & & $\mathrm{C}$ & & \begin{tabular}{l|l}
$\mathrm{R}$ & $\mathrm{R}$ \\
\end{tabular} & & $\mathrm{C}$ & $\mathrm{C}$ & & \begin{tabular}{|l|}
$\mathrm{R}$ \\
\end{tabular} & & $\mathrm{C}$ & & & R & & & & $\mathrm{R}$ & $\mathrm{R}$ & $\begin{array}{ll}\mathrm{R} \\
\end{array}$ & $\mathrm{R}$ & & & & C & $\mathrm{C}$ \\
\hline & & $54,64-66$ & C & $\mathrm{G}$ & C & & C & C & $\mathrm{R}$ & & C & $\mathrm{A}$ & & c & & A & $\mathrm{A}$ & & $\mathrm{R}$ & & $\mathrm{c}$ & \begin{tabular}{l|l}
$c$ & $R$ \\
\end{tabular} & & C & & \begin{tabular}{l|l}
$R$ & $C$ \\
\end{tabular} & C & $\mathrm{R}$ & $\mathrm{R}$ & C & C & $R$ & & & C & \\
\hline & & $6-5,110-112$ & C & M & $\begin{array}{ll} \\
\end{array}$ & & & $\mathrm{R}$ & & & $\mathrm{R}$ & $\mathrm{A}$ & & $\mathrm{R}$ & & C & C & & & & c & $\begin{array}{ll}c & R \\
\end{array}$ & & $\mathrm{R}$ & & & & $\mathrm{R}$ & $\mathrm{R}$ & C & C & $\mathrm{R}$ & $R$ & & $\mathrm{R}$ & \\
\hline & & $7-5,40-42$ & C & \begin{tabular}{|l|l|}
$P$ \\
\end{tabular} & C & & $\mathrm{R}$ & $\mathrm{R}$ & & & $\mathrm{R}$ & $\mathrm{A}$ & & $\mathrm{R}$ & & C & $\mathrm{A}$ & & $\mathrm{R}$ & $\mathrm{R}$ & C & \begin{tabular}{c|l}
$c$ & $R$ \\
\end{tabular} & & C & & & $\mathrm{R}$ & C & c & C & C & $R$ & & & c & \\
\hline & & $8 \cdot 3,40-42$ & C & $\mathrm{M}$ & \begin{tabular}{|l|l|} 
& \\
\end{tabular} & & & & $\mathrm{R}$ & & $\mathrm{R}$ & C & & \begin{tabular}{l|l}
$\mathrm{R}$ & $\mathrm{R}$ \\
\end{tabular} & \begin{tabular}{l|l}
$R$ & $R$ \\
\end{tabular} & R C & C & $\mathrm{R}$ & \begin{tabular}{|l|}
$\mathrm{R}$ \\
\end{tabular} & & $\mathrm{R}$ & $\mathrm{R}$ & & & & $c$ & c & $\mathrm{R}$ & $\mathrm{R}$ & $\mathrm{R}$ & & & & & $\mathrm{R}$ & \\
\hline & & $9-2,90-92$ & C & $\mathrm{M}$ & C & & & & & & $\mathrm{R}$ & C & & & & A & C & & & & & $\mathrm{R}$ & & & & & C & $\mathrm{R}$ & c & $\mathrm{R}$ & C & & & & C & \\
\hline & & $10-2,100-102$ & C & \begin{tabular}{l|l} 
\\
\end{tabular} & C & & & & $\mathrm{R}$ & & $\mathrm{R}$ & C & & C & $\mathrm{R}$ & $\begin{array}{ll}\mathrm{R} & \mathrm{A} \\
\end{array}$ & A & & & $\mathrm{R}$ & C & $\mathrm{R}$ & & & & & c & $\mathrm{R}$ & c & $\mathrm{R}$ & c & $\mathrm{R}$ & & & c & \\
\hline & & $11-2,110-112$ & C & \begin{tabular}{|l|l|}
$P$ \\
\end{tabular} & C & & & & & & $\mathrm{R}$ & C & & $\mathrm{R}$ & & C & $\mathrm{R}$ & & & & C & $\mathrm{R}$ & & & & & $\mathrm{R}$ & & & $\mathrm{R}$ & $\mathrm{R}$ & & & & $\mathrm{R}$ & \\
\hline & & $12-2,90-92$ & $\mathrm{R}$ & \begin{tabular}{|l|l|l}
$\mathrm{P}$ \\
\end{tabular} & \begin{tabular}{|l|l|}
$\mathrm{R}$ \\
\end{tabular} & & & & & & & & & & & R & $\mathrm{R}$ & & & & $\mathrm{C}$ & & & & & & R & & & & $\mathrm{R}$ & & & & R & \\
\hline & & $13-2,110-112$ & $\mathrm{R}$ & \begin{tabular}{|l|l|}
$P$ \\
\end{tabular} & $\mathrm{R}$ & & & & & & & C & & $\mathrm{R}$ & \begin{tabular}{l|l}
$\mathrm{R}$ & $\mathrm{R}$ \\
\end{tabular} & $\begin{array}{lll}\mathrm{R} & \mathrm{C} \\
\mathrm{R}\end{array}$ & $\mathrm{R}$ & & & & C & & & & & & $\mathrm{R}$ & & & $\mathrm{R}$ & $\mathrm{R}$ & & & & C & \\
\hline & & $14-2,110-112$ & $\mathrm{R}$ & $\mathrm{P}$ & $\mathrm{R}$ & & $\mathrm{R}$ & & & & & $\mathrm{R}$ & & & & $\mathrm{R}$ & $\mathrm{R}$ & & & & & & & & & & R & & & \begin{tabular}{|l|l|}
$\mathrm{R}$ \\
\end{tabular} & $\mathrm{R}$ & & & & R & \\
\hline & & $15-2,110-112$ & $\mathrm{R}$ & $\mathrm{P}$ & & & & & & & & $\mathrm{R}$ & & & & $\mathrm{R}$ & & & & & $\mathrm{R}$ & & & & & & $\mathrm{R}$ & & & & & & & & $\mathrm{R}$ & \\
\hline & & $16-2,110-112$ & $\mathrm{R}$ & $\mathrm{P}$ & & & & & & & & $\mathrm{R}$ & & & & $\mathrm{C}$ & R & & & & & & & & & & $\mathrm{R}$ & & & & R & & & & \begin{tabular}{l|l} 
R & I \\
\end{tabular} & $\mathbf{R}$ \\
\hline & & $17-2,110-112$ & C & $\mathrm{P}$ & \begin{tabular}{|l|l|}
$R$ \\
\end{tabular} & & & & & & $\mathrm{R}$ & C & & & & $\mathrm{C}$ & $\mathrm{C}$ & & & & $\mathrm{R}$ & & & & & & $\mathrm{R}$ & $\mathrm{R}$ & & $\mathrm{R}$ & $\begin{array}{ll}C_{1} \\
\end{array}$ & & $\mathrm{R}$ & & \begin{tabular}{c|c} 
C & 1 \\
\end{tabular} & $\mathrm{R}$ \\
\hline & & $18-2,110-112$ & $\mathrm{R}$ & $\mathrm{P}$ & & & & & & & & $\mathrm{R}$ & & & & $\mathrm{R}$ & & & & & $\mathrm{R}$ & $\mathrm{R}$ & & & & & R & & & & $\mathrm{R}$ & & & & C & \\
\hline & & $19-2,110-112$ & $\mathrm{R}$ & $\mathrm{P}$ & $\mathrm{R}$ & & & & & & & $\mathrm{R}$ & & & & & R & & & & $\mathrm{R}$ & & & & & & & & & & \begin{tabular}{l|l}
$\mathrm{R}$ \\
\end{tabular} & & & & C 1 & $\mathrm{R}$ \\
\hline & & $1 \mathrm{~A}-3,110-112$ & $\mathrm{R}$ & $\mathrm{P}$ & $\mathrm{R}$ & & $\mathrm{R}$ & & $R$ & & & $\mathrm{R}$ & & & \begin{tabular}{l|l}
$R$ & $R$ \\
\end{tabular} & \begin{tabular}{l|l}
$\mathrm{R}$ & $\mathrm{R}$ \\
\end{tabular} & C & & $\mathrm{R}$ & & $\mathrm{R}$ & & & & & & $\mathrm{R}$ & & & \begin{tabular}{|l|l}
$\mathrm{R}$ \\
\end{tabular} & & $\mathrm{R}$ & & \begin{tabular}{l|l}
$\mathrm{R}$ & $\mathrm{F}$ \\
\end{tabular} & \begin{tabular}{l|l}
$\mathrm{R}$ \\
\end{tabular} & \\
\hline & & $2 A \cdot 2,65-67$ & C & \begin{tabular}{|l|}
$P$ \\
\end{tabular} & $\mathrm{R}$ & & $\mathrm{R}$ & & & & & C & & \begin{tabular}{l|l}
$\mathrm{R}$ & $\mathrm{F}$ \\
\end{tabular} & $\begin{array}{lll}\mathrm{R} & \mathrm{R} \\
\end{array}$ & $\begin{array}{lll}\mathrm{R} & \mathrm{C} \\
\end{array}$ & C & $R$ & $\mathrm{R}$ & & C & R & & & & & $\mathrm{R}$ & $R$ & & \begin{tabular}{|l|l}
$R$ \\
\end{tabular} & C & $R$ & & & C & \\
\hline & & $3 A-2,60-62$ & C & $\mathrm{P}$ & \begin{tabular}{|l|}
$\mathrm{R}$ \\
\end{tabular} & & & & $\mathrm{R}$ & & & C & & \begin{tabular}{c|c}
$\mathrm{R}$ & $\mathrm{F}$ \\
\end{tabular} & $\begin{array}{ll}\mathrm{R} & \mathrm{R} \\
\end{array}$ & $\begin{array}{lll}\mathrm{R} & \mathrm{C} \\
\end{array}$ & $\mathrm{C}$ & $\mathrm{R}$ & $\mathrm{R}$ & & $\mathrm{R}$ & $\mathrm{R}$ & & $\mathrm{R}$ & & & $\mathrm{R}$ & & & $\mathrm{R}$ & C & $\mathrm{R}$ & & \begin{tabular}{l|l}
$\mathrm{R}$ & $\mathrm{C}$ \\
\end{tabular} & C & \\
\hline & & $4 A-2,82-84$ & A & $\mathrm{M}$ & C & & $\mathrm{R}$ & $\mathrm{R}$ & C & & & A & & c & & $\mathrm{A}$ & $\mathrm{A}$ & & $\mathrm{R}$ & & $\mathrm{R}$ & $\mathrm{C}$ & & C & & & c) & $R$ & & A & A & C & & \begin{tabular}{l|l}
$\mathrm{R}$ & $\mathrm{C}$ \\
\end{tabular} & C & \\
\hline & & $5 A-2,48-50$ & $\mathrm{R}$ & $\mathrm{P}$ & $\mathrm{R}$ & & & & & & & $\mathrm{R}$ & & R & $\mathrm{R}$ & $\mathrm{R}$ & & & & & & & & & & & & & & & & & & & \begin{tabular}{l|l} 
R & \\
\end{tabular} & \\
\hline & & $6 \mathrm{~A}-2,50-52$ & C & $\mathrm{P}$ & C & & $\mathrm{R}$ & & & & & \begin{tabular}{l|l}
$\mathrm{C}$ & $\mathrm{B}$ \\
\end{tabular} & $\bar{R}$ & & \begin{tabular}{l|l}
$R$ & $R$ \\
\end{tabular} & \begin{tabular}{l|l}
$R$ & $C$ \\
\end{tabular} & $R$ & $R$ & & & $\mathrm{R}$ & & & & & & $R$ & & & & & & & $\mathrm{R}$ & $\mathrm{R}$ & \\
\hline & & $7 \mathrm{~A}-2,60-62$ & C & \begin{tabular}{|l|l|}
$P$ \\
\end{tabular} & C & & $\mathrm{R}$ & & & & & C & & \begin{tabular}{c|c}
$\mathrm{C}$ & $\mathrm{F}$ \\
\end{tabular} & \begin{tabular}{l|l}
$R$ & $R$ \\
$R$
\end{tabular} & $\begin{array}{lll}\text { R } & C \\
\end{array}$ & C & c & $\mathrm{R}$ & & $\mathrm{R}$ & $\bar{R}$ & & R & & & R & & & $\begin{array}{ll}R \\
\end{array}$ & $\mathrm{R}$ & & & & $\mathrm{R}$ & \\
\hline
\end{tabular}




\section{SITE 234}

\section{Geologic and Stratigraphic Setting}

Site 234 , in a water depth of 4740 meters, is located near the western margin of the Somali Basin. Two penetrations, discontinuously cored, were made; the second was abandoned for technical difficulties after a single core at 247 meters. The paucity and poor preservation of microfossils made age assignments difficult. The Neogene section includes 11 meters of Pliocene to upper Miocene sediments overlying 150 meters of lower and middle Miocene sediments.

The Pliocene to upper Miocene sequence consists of slowly accumulating $(1 \mathrm{~m} / \mathrm{m} . \mathrm{y}$. average) calcareous sediments, the slow sedimentation being conducive to manganese nodule formation at the sediment surface. Lower and middle Miocene sediments, which consist of alternating clay and calcareous muds, accumulated more rapidly with an average rate of about $13 \mathrm{~m} / \mathrm{m} . \mathrm{y}$.

The site must have been close to the CCD throughout the time of deposition.

\section{Abundance and Preservation of Foraminifera}

Only Core 1 (lithologic Unit 1) yielded a significant amount of coarse sediment fraction $(>63 \mu)$. Poorly preserved foraminifera are common in the horizons $0-10 \mathrm{~cm}$, 2.26 meters, and 9.5 meters, and are rare in the other horizons of Core 1. They show extensive signs of dissolution, being poorly diversified and highly fragmented, and including only species with robust tests resistant to solution. The remaining components of Core 1 coarse fraction include quartz grains, mica flakes, sponge spicules, fish teeth, echinoderm debris, and radiolarians.

Below Core 1 , no residue coarser than $63 \mu$ was recovered except in a few horizons. The latter yielded a very small amount of coarse fraction containing benthic foraminifera, unidentifiable planktonic foraminiferal debris, quartz grains, fish teeth, sponge spicules, and radiolarians, often pyritized.

\section{Planktonic Foraminiferal Zonation}

The planktonic assemblage in the interval of Core 1, Section 1 to Section 4 contains modern species ranging back at least to the Pliocene. No diagenetic species were found for differentiation between Quaternary and Pliocene. However, the presence of primitive forms of Sphaeroidinella dehiscens indicate a probable early Pliocene age (N.20-N.19). The planktonic faunas from Core 1, Sections 5 and 6 appear to be lowermost early Pliocene (N.18) as indicated by the presence of Sphaeroidinellopsis spp., Globorotalia tumida tumida, G. tumida plesiotumida, Globoquadrina altispira, and Globigerina nepenthes.

\section{SITE 235}

\section{Geologic and Stratigraphic Setting}

Site 235 , in a water depth of 5140 meters, is located in the Somali Basin at the westernmost edge of the abyssal plain that onlaps the eastern flank of Chain Ridge. The sedimentary sequence, which was intermittently cored, consists of 500 meters of nannofossil clays and nannofossil oozes ranging from Quaternary to middle Miocene, and 247 meters of undated brown clay devoid of microfossils overlying the basement of Late Cretaceous age.

The average rate of accumulation of the dated Neogene sequence is $37 \mathrm{~m} / \mathrm{m} . \mathrm{y}$., a very high value compared to the average rate of $5 \mathrm{~m} / \mathrm{m} . \mathrm{y}$. for the equivalent strata at Site 234. The high rate of accumulation at Site 235 results from the influx of displaced shallower sediments from either Chain Ridge or Carlsberg Ridge. This is evidenced by the higher content and better preservation of calcareous material and a higher planktonic/benthic foraminiferal ratio (>99\% planktonic) than would be normally expected in a water depth greater than 5000 meters, as well as by the presence in some horizons of pteropods and bivalve debris.

\section{Abundance and Preservation of Foraminifera}

The sediments of Site 235 yielded an extremely small coarse fraction $(>63 \mu)$ throughout the section. A larger amount of coarse fraction was recovered in some silty and sandy horizons. In these horizons, uniformly minute foraminifera are common to abundant. Despite the great depth of water at the site this fauna is well preserved; it is probably displaced from shallower depths and may represent the distal parts of turbidite layers.

Except for this distinct, well-sorted foraminiferal fauna, foraminifera show a significant degree of dissolution. The fauna is poorly diversified, the tests are highly fragmented, and only those species resistant to solution are present. Calcareous nannofossils, however, are common and moderately preserved throughout the Neogene section.

\section{Planktonic Foraminiferal Zonation}

Due to the paucity and poor preservation of the planktonic foraminifera recovered at Site 235, biostratigraphic investigation could be conducted only at a few horizons.

The presence of Globorotalia truncatulinoides in Cores 1 to 5 indicates a Quaternary age for this interval. Core 7 appears to be late Pliocene in age (N.21) as shown by the co-occurrence of Neogloboquadrina dutertrei and Pulleniatina primalis. Core 8 and the upper part of Core 9, which contain Globorotalia tumida, Globoquadrina altispira, and Pulleniatina spp., are assigned to the early Pliocene Zones N.20-N.19, and Sample 9, CC, which includes Globorotalia tumida plesiotumida, is assigned to N.18. Core 10 yielded a similar planktonic assemblage but without $G$. tumida. Because of the absence of this species, Core 10 is attributed to N.17.

The debris of planktonic foraminifera (mainly fragmented keels of Globorotalia) found in Core 6 and below 228 meters (Cores 11 to 16 ) do not permit a zonal assignment for these intervals.

\section{SITE 236}

\section{Geologic and Stratigraphic Setting}

Site 236, in a water depth of 4504 meters, is located in the outermost foothills southwest of the Carlsberg Ridge, 
TABLE 5

Distribution of Selected Neogene Planktonic Foraminifera at Site 236

\begin{tabular}{|c|c|c|c|c|c|c|c|c|c|c|c|c|c|c|c|c|c|c|c|c|c|c|c|c|c|c|c|c|c|c|c|c|c|c|c|c|c|c|c|c|c|c|c|c|c|c|c|c|}
\hline$\stackrel{8}{4}$ & క్․ & $\begin{array}{c}\text { Sample } \\
\text { (Interval } \\
\text { in } \mathrm{cm} \text { ) }\end{array}$ & 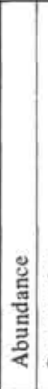 & : & & 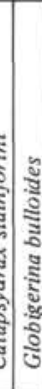 & & : & & 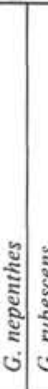 & 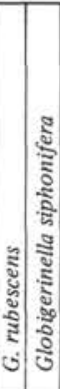 & 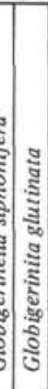 & 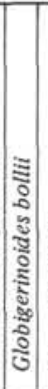 & ن. & 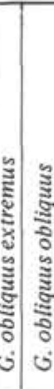 & 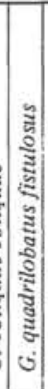 & 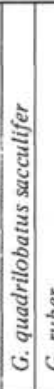 & نั & $\mid$ & 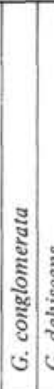 & 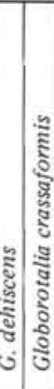 & $\frac{a}{\frac{a}{3}}$ & (u) & ن: & : & 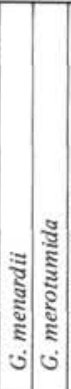 & 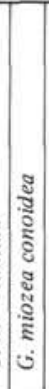 & 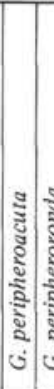 & 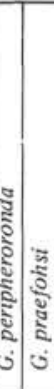 & 胥 & : & 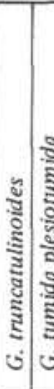 & 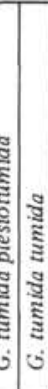 & 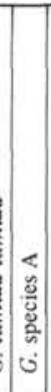 & 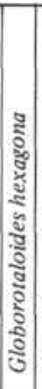 & 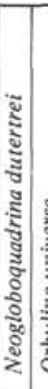 & 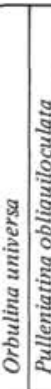 & 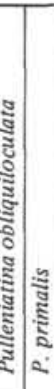 & 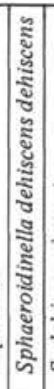 & 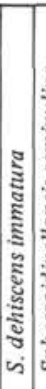 & 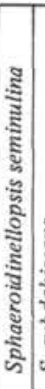 & 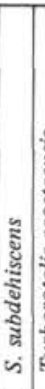 & 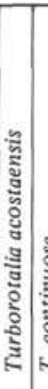 & & 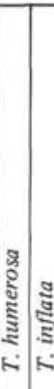 & 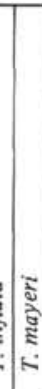 & 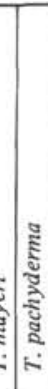 & : \\
\hline \multirow{8}{*}{ 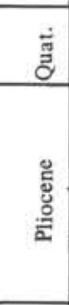 } & N23- & $1-2,24-2$ & A & $\mathbf{P}$ & & C & & & & & \begin{tabular}{l|l}
$A$ & $R$ \\
\end{tabular} & A & & $\mathrm{R}$ & & & \begin{tabular}{|l|l}
$A$ & $A$
\end{tabular} & $\mathrm{~A} C$ & & & A & & & & & $\mathrm{A}$ & & & & c & & & A & & C & A & & C & $R$ & & & & & & & & C & \\
\hline & $\mathrm{N} 22$ & $2-1,138-140$ & $\mathrm{~A}$ & \begin{tabular}{|l|l|}
$\mathbf{P}$ \\
\end{tabular} & & $\mathrm{C}$ & & & & & $\begin{array}{ll}\mathrm{C} & \mathrm{R} \\
\end{array}$ & C & & $\mathrm{R}$ & & & \begin{tabular}{|l|l}
$A$ & $A$
\end{tabular} & A & & & $\mathrm{R}$ & & $\mathrm{R}$ & & & $\mathrm{A}$ & & & & $\mathrm{R}$ & & $\mathrm{C}$ & A & & & $\mathrm{A}$ & & A & c & c & & & & & \begin{tabular}{l|l}
$\mathrm{C}$ & $\mathrm{C}$ \\
$\mathrm{C}$
\end{tabular} & & & \\
\hline & \multirow{3}{*}{$\mathrm{N} 21$} & \begin{tabular}{|l|}
$3-2,72-74$ \\
$4-3,16-18$ \\
\end{tabular} & \begin{tabular}{|l|}
$\mathrm{A}$ \\
$\mathrm{A}$
\end{tabular} & \begin{tabular}{|l|l|}
$M$ & \\
$M$ &
\end{tabular} & & $\frac{\mathrm{C}}{\mathrm{C}}$ & $R$ & A & & & \begin{tabular}{|l|l|}
$A$ & $C$ \\
$A$ & $C$ \\
\end{tabular} & $\begin{array}{l}\mathrm{A} \\
\mathrm{B}\end{array}$ & & \begin{tabular}{l|l}
$\mathrm{C}$ & \\
$\mathrm{C}$ &
\end{tabular} & + & $R$ & \begin{tabular}{|l|l|l}
$A$ & $A$ \\
$A$ & $A$
\end{tabular} & $\mathrm{~A}$ & \begin{tabular}{|l|}
$\mathrm{R}$ \\
$\mathrm{R}$
\end{tabular} & \begin{tabular}{|l}
$R$ \\
$C$
\end{tabular} & \begin{tabular}{|l|}
$R$ \\
$R$
\end{tabular} & & & \begin{tabular}{|l} 
\\
$C$
\end{tabular} & 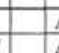 & \begin{tabular}{|c|}
$\mathrm{A}$ \\
$\mathrm{A}$
\end{tabular} & & & & \begin{tabular}{|l|}
$\mathrm{C}$ \\
$\mathrm{C}$
\end{tabular} & C & & \begin{tabular}{|l|}
$\mathrm{A}$ \\
$\mathrm{C}$ \\
\end{tabular} & & \begin{tabular}{|l|}
$R$ \\
$C$
\end{tabular} & \begin{tabular}{l|l}
$\mathrm{C}$ & $\mathrm{C}$ \\
$\mathrm{R}$ & $\mathrm{C}$
\end{tabular} & \begin{tabular}{l|l}
$\mathrm{C}$ & $\mathrm{C}$ \\
$\mathrm{C}$ & $\mathrm{C}$
\end{tabular} & $\frac{\mathrm{c}}{\mathrm{c}}$ & \begin{tabular}{|l|}
$\mathrm{c}$ \\
$\mathrm{c}$
\end{tabular} & \begin{tabular}{|l|}
$\mathrm{C}$ \\
$\mathrm{R}$ \\
\end{tabular} & + & 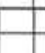 & & & $\begin{array}{l}\mathrm{A} \\
\mathrm{A}\end{array}$ & & L & \\
\hline & & \begin{tabular}{|l|}
$4-3,16-18$ \\
$4-5,85-87$ \\
\end{tabular} & \begin{tabular}{|l|}
$\mathrm{A}$ \\
$\mathrm{A}$ \\
\end{tabular} & \begin{tabular}{|l|l}
$\mathrm{M}$ \\
$\mathrm{M}$
\end{tabular} & & $\frac{C}{R}$ & & $|\mathrm{~A}|$ & & & \begin{tabular}{l|l}
$\mathrm{A}$ & $\mathrm{C}$ \\
$\mathrm{C}$ & $\mathrm{R}$ \\
\end{tabular} & $\begin{array}{l}R \\
\end{array}$ & & & $\begin{array}{ll}\mathrm{C} & \mathrm{A} \\
\end{array}$ & & \begin{tabular}{|l|l|}
$\mathrm{A}$ & $\mathrm{A}$ \\
$\mathrm{A}$ & $\mathrm{A}$ \\
\end{tabular} & $\frac{A}{A}$ & $\frac{\mathrm{R}}{\mathrm{C}}$ & \begin{tabular}{|l}
$\mathrm{C}$ \\
$\mathrm{R}$ \\
\end{tabular} & \begin{tabular}{|l}
$R$ \\
$R$ \\
\end{tabular} & & & \begin{tabular}{|l} 
R \\
\end{tabular} & & $\begin{array}{l}\mathrm{A} \\
\mathrm{A}\end{array}$ & & & & C & $\mathrm{R}$ & & \begin{tabular}{|l} 
C \\
\end{tabular} & & \begin{tabular}{|l|} 
\\
$\mathrm{c}$ \\
\end{tabular} & \begin{tabular}{l|l}
$\mathrm{R}$ & $\mathrm{C}$ \\
$\mathrm{R}$ & $\mathrm{H}$ \\
\end{tabular} & $\begin{array}{lll}C & C \\
R & C \\
\end{array}$ & $\frac{c}{c}$ & \begin{tabular}{|l|}
$\mathrm{C}$ \\
$\mathrm{R}$ \\
\end{tabular} & \begin{tabular}{|l|}
$R$ \\
$R$ \\
\end{tabular} & & & & & $\begin{array}{l}\mathrm{A} \\
\mathrm{C}\end{array}$ & & & \\
\hline & & \begin{tabular}{|l|}
$5-1,86-88$ \\
\end{tabular} & C & $\mathrm{M}$ & & C & & A & & & $\begin{array}{ll}\mathrm{A} & \mathrm{C} \\
\end{array}$ & C & & \begin{tabular}{l|l}
$\mathrm{R}$ & $\mathrm{A}$ \\
\end{tabular} & A & & \begin{tabular}{|l|l|l|l|l}
$A$ & $A$
\end{tabular} & $\mathrm{~A}$ & c & C & $\mathrm{R}$ & & & & & C & & & & $\mathrm{R}$ & c & & $\mathbf{R}$ & & $\mathrm{R}$ & $\mathrm{R} / \mathrm{C}$ & $\begin{array}{ll}\text { C } & A \\
\end{array}$ & A & & \begin{tabular}{|l|l|}
$\mathrm{R}$ \\
\end{tabular} & $\mathrm{R}$ & A & & & $\mathrm{A}$ & & $R$ & \\
\hline & $\begin{array}{l}\mathrm{N} 20- \\
\mathrm{N} 19 ?\end{array}$ & $5-3,5-7$ & C & G & & $\mathrm{R}$ & & $\mathrm{R}$ & & & \begin{tabular}{l|l|}
$R$ & $R$ \\
\end{tabular} & R & & $\mathrm{R}$ & $\begin{array}{ll}\mathrm{R} & \mathrm{C} \\
\end{array}$ & & \begin{tabular}{|l|l|}
$R$ & $F$ \\
\end{tabular} & $\mathrm{R}$ & & & & & & & & & & & & & & & & & & & & & & & & & & & & & $R$ & \\
\hline & N18 & $5-6,70-72$ & $\mathrm{~A}$ & $\mathrm{M}$ & $R$ & c & & $\mathrm{A}$ & & & $\mathrm{A}$ & $A$ & & $\mathrm{~A}$ & $\mathrm{AC}$ & & \begin{tabular}{l|l}
$A$ & $A$ \\
\end{tabular} & $\mathrm{~A}$ & $\mathrm{~A}$ & $\mathrm{R}$ & A & & & $\mathrm{A}$ & $R$ & & & & & C & & $\mathrm{R}$ & & & C & & \begin{tabular}{l|l}
$\mathrm{A}$ & $\mathrm{A}$ \\
$\mathrm{A}$
\end{tabular} & $\mathrm{A}$ & & & C & & & & $\mathrm{A}$ & & $\mathrm{R}$ & \\
\hline & N18 & \begin{tabular}{|l|}
$6-2,90-92$ \\
\end{tabular} & \begin{tabular}{l|l} 
C \\
\end{tabular} & $\mathrm{P}$ & & C & $\mathrm{R}$ & C & & $R$ & C & $\mathrm{R}$ & & & $\begin{array}{ll}\mathrm{R} & \mathrm{A} \\
\end{array}$ & & C & & $\mathrm{R}$ & $\mathrm{R}$ & & & & C & $\mathrm{R}$ & C & & & & & & $\mathrm{R}$ & $\begin{array}{ll}\mathrm{R} \\
\mathrm{B}\end{array}$ & & & & & R & & & $\mathrm{R}$ & $\mathrm{R}$ & & & $\mathrm{R}$ & & & \\
\hline \multirow{14}{*}{ 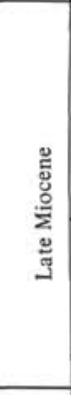 } & \multirow{8}{*}{ N17 } & $6-5,82-84$ & A & M & & C & & A & & $\mathrm{R}$ & C & $\mathrm{C}$ & & A & $\begin{array}{ll}\mathrm{A} & \mathrm{A} \\
\end{array}$ & & A & & C & & & & & A & A & $\mathrm{A}$ & & & & $\mathrm{R}$ & & C & & & C & & \begin{tabular}{l|l}
$\mathrm{A}$ & $\mathrm{A}$ \\
$\mathrm{A}$
\end{tabular} & A & & & C & C & & & $\mathrm{A}$ & & $\mathrm{R}$ & \\
\hline & & $7-5,30-32$ & \begin{tabular}{|l|} 
A \\
\end{tabular} & $\mathrm{M}$ & & A & & A & & c & C & A & & C & \begin{tabular}{c|c} 
C & $A$ \\
\end{tabular} & & $\mathrm{ACC}$ & C & \begin{tabular}{|l|l|}
$R$ \\
\end{tabular} & $\mathrm{R}$ & & & & $\mathrm{R}$ & C & C & & & & $\mathrm{R}$ & & $\mathrm{C}$ & c. & & C & & \begin{tabular}{c|c} 
C & C \\
\end{tabular} & $\begin{array}{c}c \\
c\end{array}$ & & & & & $R$ & & C & & $\frac{R}{R}$ & \\
\hline & & $7-5,113-115$ & A & $\mathrm{P}$ & & A & & A & & $\mathrm{A}$ & C & $A$ & & & $\begin{array}{ll}\text { A } & R \\
\end{array}$ & & $\mathrm{~A} C \mathrm{C}$ & C & C & $\mathrm{R}$ & & & & A & $R$ & C & & & & C & & C & & & C & & $A C$ & \begin{tabular}{l|l} 
& $R$ \\
\end{tabular} & & & & & C & & $\mathrm{A}$ & & $\mathrm{R}$ & \\
\hline & & $8-3,3=$ & $\begin{array}{ll}\text { C } \\
\end{array}$ & $\mathrm{P}$ & & $\mathrm{R}$ & & $\mathrm{R}$ & & $R$ & $\mathrm{R}$ & ( C & & & $\mathrm{R} C$ & & $\mathrm{R}$ & & $\mathrm{R}$ & $\mathrm{R}$ & & & & C & & $R$ & & & & ( & & $\mathrm{R}$ & & & & & \begin{tabular}{l|l}
$\mathrm{R}$ & $\mathrm{R}$ \\
\end{tabular} & \begin{tabular}{l|l}
$\mathbf{R}$ & $\mathrm{R}$ \\
\end{tabular} & & & $\rightarrow$ & $\mathrm{R}$ & & & & & $\bar{R}$ & \\
\hline & & $8-5.137-139$ & C & & & $\mathrm{R}$ & & $\mathrm{R}$ & & c & $R$ & $\begin{array}{ll}2 & R \\
\end{array}$ & & \begin{tabular}{l|l}
$R$ & $R$ \\
\end{tabular} & $\mathrm{R} C$ & & \begin{tabular}{l|l}
$\mathrm{C}$ & $\mathrm{F}$ \\
\end{tabular} & $\mathrm{R}$ & $\begin{array}{ll}R \\
\end{array}$ & $\mathrm{C}$ & & & & C & & c & & & & R & & $\mathrm{R}$ & & & - & & $\mathrm{R}$ & & & & \begin{tabular}{l|l}
$\mathrm{R}$ \\
\end{tabular} & c & $\mathrm{R}$ & & $\mathrm{R}$ & & - & \\
\hline & & $9-2.111-113$ & \begin{tabular}{|l|l} 
A \\
\end{tabular} & $P$ & & A & & $\mathrm{R}$ & & c & C & $\mathrm{A}$ & & $\mathrm{C}$ & C $\mathrm{A}$ & & A $\mathrm{F}$ & $\mathrm{R}$ & $\mathrm{R}$ & $R$ & & & & C & & $R$ & & & & c & & $\mathrm{R}$ & R & & $R$ & & \begin{tabular}{c|c}
$\mathrm{C}$ & $\mathrm{R}$ \\
\end{tabular} & $\begin{array}{ll}\mathrm{R} & \mathrm{R} \\
\end{array}$ & & & 7 & C & $\mathrm{R}$ & & C & & - & \\
\hline & & $9-4,68-70$ & \begin{tabular}{|l|l} 
A & \\
\end{tabular} & $\mathrm{P}$ & & C & & R & & A & A & $\begin{array}{ll}A & A \\
\end{array}$ & & $\begin{array}{ll}R & C \\
\end{array}$ & \begin{tabular}{c|c}
$c$ & $C$ \\
\end{tabular} & & \begin{tabular}{ll|l}
$A$ & $B$ \\
\end{tabular} & $\mathbf{R}$ & $\mathrm{R}$ & R & $R$ & & & C & & C & & & & $R$ & & $\mathrm{R}$ & & C & ( & & \begin{tabular}{l|l}
$A$ & $B$ \\
\end{tabular} & $\begin{array}{ll}\mathrm{R} & \mathrm{C} \\
\end{array}$ & & & & $\mathrm{R}$ & c & & c & & & \\
\hline & & $10-3,83-85$ & \begin{tabular}{|l|l} 
C \\
\end{tabular} & $\mathrm{P}$ & & $\mathrm{R}$ & & $\mathrm{R}$ & & c & C & $\mathrm{R}$ & & \begin{tabular}{l|l}
$\mathrm{R}$ & $\mathrm{B}$ \\
\end{tabular} & $\begin{array}{ll}\mathrm{R} & \mathrm{A} \\
\end{array}$ & & $\begin{array}{ll}A & \mathrm{~B} \\
\end{array}$ & $\mathrm{R}$ & $\mathrm{R}$ & $\begin{array}{ll}R & 1 \\
\end{array}$ & \begin{tabular}{l|l}
$R$ & $R$ \\
\end{tabular} & & & $\mathrm{R}$ & & & $\mathrm{R}$ & & & $\mathrm{R}$ & & $\mathrm{R}$ & & & 5 & & & \begin{tabular}{l|l}
$R$ & $R$ \\
\end{tabular} & & & & $\mathrm{R}$ & & & C & & & \\
\hline & \multirow{6}{*}{ N16 } & $11-2,16-18$ & C & $P$ & & c & & C & & $\mathrm{A}$ & & A & & & C & & $\mathrm{APB}$ & $R$ & $R$ & & & & c & \begin{tabular}{l|l}
$C$ & $R$ \\
\end{tabular} & & 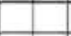 & & & & $R$ & & & & & C & & c & & & & & & C & & C & & & \\
\hline & & $12-3$, & c & & & c & & c & & A & C & A & & & $\mathbf{R}$ & & $\mathrm{AB}$ & $\mathrm{R}$ & $\mathrm{R}$ & R I & $\mathrm{R}$ & & $\mathrm{R}$ & R C & & & $R$ & & & C & & & & & c & & c & & & & & & $\mathrm{A}$ & & & & & \\
\hline & & \begin{tabular}{|c|}
$12-5,95-97$ \\
\end{tabular} & C & $\mathrm{P}$ & & C & & 7 & & 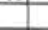 & C & $\mathrm{R}$ & & & R & & A & & $\mathrm{R}$ & & c & & 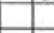 & C & & 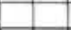 & & & & $\mathrm{R}$ & & & & & $R$ & & C & & & & & & C & & & & & \\
\hline & & $13-2,116-118$ & \begin{tabular}{|l|}
$\mathrm{C}$ \\
\end{tabular} & \begin{tabular}{|l|l|} 
\\
\end{tabular} & & A & & $\mathrm{R}$ & & C & C & $\mathrm{C}$ & & \begin{tabular}{|l|l|}
$R$ \\
\end{tabular} & $\mathrm{~A}$ & & A & & $\mathrm{C}$ & & & & & A & & C & & & & $\mathrm{R}$ & & & & C & & & $\pi$ & & & & & C & C & & & & & \\
\hline & & $13-6$, & A & $P$ & & $\mathrm{R}$ & & $\mathrm{R}$ & & $\mathrm{R}$ & $\mathrm{R}$ & $\begin{array}{ll}8 & C \\
\end{array}$ & & & A & & C & & $\mathrm{R}$ & $\mathrm{R}$ & & & $\mathrm{R}$ & \begin{tabular}{l|l}
$R$ & $C$ \\
\end{tabular} & & $\mathrm{R}$ & & & & $\mathrm{R}$ & & & & & & & & & & & $\mathrm{R}$ & $\mathbf{R}$ & $\mathrm{R}$ & & & & & \\
\hline & & \begin{tabular}{|l|l|}
$14-2,51-53$ \\
\end{tabular} & C & $\mathrm{P}$ & & C & & \begin{tabular}{|l|l|l|} 
C \\
\end{tabular} & $\begin{array}{lll}\text { A } & 1 \\
\end{array}$ & $\mathrm{R}$ & $\mathrm{R}$ & $\begin{array}{ll}\mathrm{R} & \mathrm{C} \\
\end{array}$ & \begin{tabular}{|l|}
$\mathrm{R}$ \\
\end{tabular} & & A & & A & & C & C & & & & C & & $\mathrm{R}$ & & & & $\mathrm{R}$ & & & & & R & & $\mathrm{R}$ & & & & & C & \begin{tabular}{l|l}
$\mathrm{R}$ & $\mathrm{I}$ \\
\end{tabular} & $\mathrm{R}$ & & & & \\
\hline \multirow{3}{*}{ 远这 } & \multirow[b]{2}{*}{ N13 } & $15-3,10-12$ & c & $\mathbf{P}$ & & C & & & c & & $\mathrm{R}$ & R A & & & A & & C & & $\mathrm{R}$ & & & $R$ & R & $\begin{array}{ll}\mathrm{R} & \mathrm{C} \\
\end{array}$ & & $\begin{array}{l}\text { ct' } \\
\mathrm{R}\end{array}$ & & & & $\mathrm{R}$ & & & & & & & $\mathrm{R}$ & & & & $\mathrm{R}$ & c & \begin{tabular}{l|l}
$R$ & 1 \\
1
\end{tabular} & $\begin{array}{lll}\mathrm{R} & \mathrm{C} \\
\mathrm{F}\end{array}$ & $\begin{array}{l}\mathrm{ct} \\
\mathrm{R}\end{array}$ & C & C & \\
\hline & & $16-3,127-129$ & c & $\mathbf{P}$ & & $\mathrm{R}$ & & & c & & & C & $\mathbf{R}$ & & A & & c & & $\mathrm{R}$ & $\mathrm{R}$ & c & $R$ & & ${ }_{\mathrm{R}}^{\mathrm{cf}}$ & & \begin{tabular}{|l|} 
ef \\
$\mathrm{R}$
\end{tabular} & & C & & $R$ & & & & & & & & & & & & $R$ & & $\mathrm{R}$ & & c & C & \\
\hline & N11 & $17-3,120-122$ & \begin{tabular}{|l|}
$\mathrm{R}$ \\
\end{tabular} & $\mathbf{P}$ & & & & & $\mathrm{R}$ & & & & & & & & & & & & $\mathrm{R}$ & & & & & & & & & & & & & & & & & & & & & & & & & & & \\
\hline \multirow{2}{*}{ 촐ㅇํㄹ } & $\begin{array}{l}\text { N7- } \\
\text { N6 } \\
\end{array}$ & $18-4,126-128$ & $\begin{array}{ll}R \\
\end{array}$ & $\mathbf{P}$ & t & & & & & & & & & & & & $\mathrm{R}$ & & & & $\mathrm{R}$ & & & & & & & c & $\begin{array}{cll}C & C\end{array}$ & & & & & & & & & & & & & & & & & & c & \\
\hline & $?$ & $19-3,120-122$ & B & & & & & & & & & & & & & & & & & & & & & & & & & & & & & & & & & & & & & & & & & & & & & \\
\hline
\end{tabular}


$270 \mathrm{~km}$ northeast of the Seychelles Islands. The Neogene sequence, about 177 meters thick, consists of fine-grained nannofossil and foraminifera oozes with thin clay layers. Frequent coarse-grained horizons are intercalated into the fine-grained sediments throughout the Miocene and Pliocene section. The sequence from middle Miocene to Quaternary appears continuous and accumulated at an average rate of about $11 \mathrm{~m} / \mathrm{m}$.y., whereas the condensed lower Miocene section accumulated at the reduced rate of about $2 \mathrm{~m} / \mathrm{m} . \mathrm{y}$.

\section{Abundance and Preservation of Foraminifera}

Planktonic foraminifera are the dominant component of the coarse sediment fraction $(>63 \mu)$ at Site 236. Their state of preservation throughout the section is poor to moderate with a significant degree of fragmentation. In Core 1 planktonic foraminifera are poorly preserved, whereas siliceous components (radiolarians and sponge spicules) are well preserved. In Cores 2 to 15 (late Miocene and younger sediments), foraminiferal preservation varies depending on the lithologic horizon. The fine-grained nanno ooze contains planktonic foraminifera which are more poorly preserved than those found in the coarsegrained foraminiferal ooze layers. The latter may be derived from transported sediment: this suggestion is supported by the occurrence of a few transported shallow-water foraminifera in some of the coarse layers. The age of the planktonic foraminifera in the coarse layers is essentially the same as that of the associated nanno oozes. However, the evidence of some reworking of older sediments was observed in several horizons.

In Cores 15 to 19 (early and middle Miocene), the fine-grained ooze contained only a small coarse fraction, which is composed of very small foraminifera. Fish teeth are rare to common in this interval.

\section{Planktonic Foraminiferal Zonation}

Core 1 to Core 3, Section 1 are Quaternary in age, as indicated by the occurrence of Globorotalia truncatulinoides. The evolutionary transition of $G$. truncatulinoides from Globorotalia tosaensis, which marks the N.22/N.21 zonal boundary, is not well represented at this site due to the rare occurrence of $G$. truncatulinoides. This species is common only in Core 2, Section 1. The rare presence, however, of $G$. truncatulinoides in Core 3, Section 1 is the lowest observed occurrence of the species, and the zonal boundary N.22/N.21 is placed at this level. This determination is supported by the occurrence of Globigerinoides quadrilobatus fistulosus in the same horizon.

The base of Zone N.21, as defined by the lowest occurrence of G. tosaensis, lies in Core 5, Section 1. The lowest occurrence of Neogloboquadrina dutertrei and the lowest common occurrence of Globigerina rubescens, both noted in Core 5, Section 1, support this assignment; however, Globoquadrina altispira altispira, normally found in the lower part of Zones N.21 and N.20-N.19, occurs as high as Core 3 , Section 2. It is possible that this species is here reworked into younger sediments. The highest occurrence of Globorotalia margaritae, which normally lies within Zone N.20/N.19, is found in Core 5, Section 1 at the same level as the lowest occurrence of $G$. tosaensis, which delineates the base of Zone N.21. This co-occurrence may result from reworking or may reflect condensing of the Pliocene sequence. The base of Zone N.19 cannot be conclusively determined because the index species Sphaeroidinella dehiscens first appears in Core 5, Section 1 at the same level as the base of $G$. tosaensis. The N.19/N.18 zonal limit is tentatively drawn at the highest occurrence of Globorotalia tumida plesiotumida in Core 5, Section 6. The base of Zone N.18, the lowermost Pliocene zone, lies in Core 6 , Section 2, as indicated by the lowest occurrence of Globorotalia tumida tumida.

The zonal boundary N.17/N.16, based on the initial appearance of $G$. tumida plesiotumida, lies in Core 10, Section 3. An apparent unconformity separating N.16 from lower N.13, occurs between Core 13, Section 6 and Core 15 , Section 3. It is possible, however, that a condensing of Zones N.15, N.14, and upper N.13 occurs in this interval which contains a mixed fauna.

Core 15 , Section 3 to Core 16 , Section 3 are assigned to the lower part of Zone N.13 as indicated by the cooccurrence of Globorotalia fohsi and Sphaeroidinellopsis subdehiscens. Core 17 , which contains a poor planktonic fauna composed essentially of Globoquadrina dehiscens and Globigerina druryi, could not be dated with certainty but is tentatively assigned to Zone N.11. Core 18, which includes common Catapsydrax stainforthi and Globorotalia peripheroronda, is assigned to Zones N.7-N.6. Throughout the middle and lower Miocene, the foraminiferal fauna is poorly preserved, with low diversity and considerable fragmentation. Mixed faunas were often found, and several intervals yielded inadequate faunas for age determination.

\section{SITE 237}

\section{Geologic and Stratigraphic Setting}

Site 237 , in a water depth of 1630 meters, was drilled on the Mascarene Plateau in the saddle joining the granitic Seychelles Bank to the volcanic Saya de Malha Bank. The 187-meter-thick Neogene section consists of homogeneous foraminifera-rich nannofossil ooze, whic accumulated at an average rate of about $11 \mathrm{~m} / \mathrm{m} . \mathrm{y}$. during middle Miocene to Quaternary time and at a slower rate of about $3 \mathrm{~m} / \mathrm{m} . \mathrm{y}$. during early Miocene.

\section{Abundance and Preservation of Foraminifera}

The coarse sediment fraction $>63 \mu$ ) is composed almost entirely of foraminifera which are well to moderately well preserved. Planktonic species are dominant and constitute more than $99 \%$ of the foraminiferal fauna.

\section{Planktonic Foraminiferal Zonation}

Core 1 and the upper part of Core 2 belong to the Quaternary Zones N.23-N.22, as indicated by the presence of Globorotalia truncatulinoides. Core 1 contains a diverse tropical planktonic assemblage which includes common pink-colored Globigerinoides ruber. The pink variety of this species was not found in other cores at this site. The lower part of Core 2 and much of Core 3 were not recovered. Core 3, CC contained both Globorotalia truncatulinoides 
and Globorotalia tosaensis and the zonal limit N.22/N.21 (Pleistocene/Pliocene boundary) is placed at this level. It is possible, however, that Sample 3, CC includes elements of downhole mixing and that the occurrence of $G$. truncatulinoides here does not represent the first evolutionary appearance of the species. The N.21/N.20-N.19 boundary lies between Cores 4 and 5 at the base of $G$. tosaensis. The youngest appearance of Globoquadrina altispira altispira and Sphaeroidinellopsis is higher than this level but with rare occurrences; these two species occur commonly in Core 5 and below. The N.19/N.18 zonal boundary is placed below Core 6, Section 5, at the lowest occurrence of Sphaeroidinella dehiscens, a level well above the highest occurrence of Globorotalia tumida plesiotumida in Core 8, Section 5. The N. 18/N. 17 limit, which represents the Miocene/Pliocene boundary, is marked by the base of Globorotalia tumida tumida between Cores 9 and 10 .

The upper Miocene Zone N.17 is separated from the middle Miocene Zone N.13 by an interval of mixed fauna (Cores 14.2 to 15.2 ) in which upper Miocene and middle Miocene species occur together.

Core 15 , Section 3 to Core 17 , Section 5 is assigned to the lower part of Zone N.13, based on the co-occurrence of Globorotalia praemenardii, Globorotalia fohsi, Turborotalia mayeri, and Sphaeroidinellopsis subdehiscens. Core 18, Section 2 to Core 19, Section 5 is placed in the interval of N.4 to N.6 inclusive. These zones were not separated because species known to have evolved in N.6 (Sphaeroidinellopsis seminulina, Globigerinoides qaudrilobatus sacculifer) occur here with others which become extinct within, or at the top, of N.4 (Turborotalia kugleri, Turborotalia pseudokugleri). The Oligocene/Miocene boundary (N.4/P.22) appears to lie between Cores 19 and 20, at the lowest occurrence of Globigerinoides spp.

\section{SITE 238}

\section{Geologic and Stratigraphic Setting}

Site 238 , in a water depth of 2844 meters, is located at the extreme northeast end of Argo Fracture Zone, within a partly buried transform-fault cleft athwart the seismically active and spreading Central Indian Ridge.

The Neogene section, 405 meters thick, consists of foraminifera-bearing to foraminifera-rich nannofossil oozes which accumulated at an average rate of $26 \mathrm{~m} / \mathrm{m} . \mathrm{y}$. throughout post early Miocene time and at a much lower rate of about $5 \mathrm{~m} / \mathrm{m} . \mathrm{y}$. during the early Miocene. A high late Pliocene average accumulation rate (about $45 \mathrm{~m} / \mathrm{m} . \mathrm{y}$.) reflects the influx of displaced lower Pliocene sediments at that time.

\section{Abundance and Preservation of Foraminifera}

Foraminifera are the dominant component of the coarse sediment fraction $(>63 \mu)$. Planktonic species, which constitute more than $99 \%$ of the foraminiferal fauna, are diversified and well to moderately well preserved throughout the upper 281 meters (late Miocene and younger sediments) although in some horizons they show a high degree of fragmentation. Below this level, planktonic foraminifera are moderately well preserved and less diversified but with a lower degree of fragmentation. They are often of small size.

\section{Planktonic Foraminiferal Zonation}

Core 1 , Section 1 to Core 4, Section 1 penetrated Quaternary sediments (N. 23-N. 22) containing Globorotalia truncatulinoides. Pink-colored Globigerina rubescens and Globigerinoides ruber are rare to common in Core 1, Section 1 to Core 2, Section 3 and were not found below this interval. Abundant reworked early Pliocene foraminifera (N. 19) occur in the upper part of Core 1. The N. 22/N. 21 zonal boundary is drawn in Core 4, Section 1 at the lowest occurrence of Globorotalia truncatulinoides, although this level may not represent the initial evolutionary appearance of the species. The transition from Globorotalia tosaensis to $G$. truncatulinoides was not observed at Site 238 because of the presence of reworked lower Pliocene sediments directly below the Pleistocene.

Core 4, Section 2 to Core 7, Section 1 contain an early Pliocene (N.19) assemblage characterized by common Globoquadrina altispira altispira and Sphaeroidinellopsis spp. The interval from Core 7, Section 2 to Core 10, Section 5 yielded typical late Pliocene (N.21) faunas containing common Globorotalia limbata, Globigerinoides quadrilobatus fistulosus, Turborotalia humerosa, and Globigerina decoraperta, as well as rare Globorotalia tosaensis. The N.21/N.20-N.19 limit lies in Core 9, Section 1 at the lowest appearance of $G$. tosaensis and highest common occurrence of Sphaeroidinellopsis spp. The N.18/N.17 limit which marks the Miocene/Pliocene boundary, is in Core 15, Section 5 at the base of the range of Globorotalia tumida. Zones N.16 and N.15 were not identified, but may be represented by the condensed interval of Core 31 , which was not recovered. The late/middle Miocene boundary could not be defined because of the presence of a reworked fauna older than N.14 reworked into N.17(?) sediments between Cores 26 and 30. A similar mixed fauna was observed between lowermost upper Miocene and uppermost middle Miocene sediments at Sites 236 and 237.

Core 32 is assigned to Zone N.14 on the basis of the co-occurrence of Globigerina nepenthes and Turborotalia siakensis, and Cores 33, 34, and 35, which contain Sphaeroidinellopsis dehiscens and members of the Globorotalia fohsi lineage, to Zone N.13. Zone N.12 and N.11 were not identified. Core 36 is assigned to N.10 based on the co-occurrence of Globorotalia peripheroacuta and Globorotalia archaeomenardii. Core 37, which contains common Globigerinoides sicanus and rare Praeorbulina spp. and Orbulina spp. is placed within the interval of the Zone N.8 and N.9. However, the limit between the two latter zones, which defines the early/middle Miocene boundary, was not delineated because of the overlapping within Core 37 of Orbulina universa and Praeorbulina glomerosa curva. Cores 38 to 41 are assigned to Zone N.8, and the lower limit of this zone is marked by the lowest occurrence of Globigerinoides sicanus in Core 41, Section 6. Zones N.7 and N.6 were not recognized, and the highest occurrence of Globigerinoides quadrilobatus primordius, a species known to become extinct elsewhere within N.5, occurs, in the upper part of Core 42 . Cores 42 and 43, which contain Globigerinoides quadrilobatus primordius, Globoquadrina dehiscens, and Globoquadrina dehiscens praedehiscens, were assigned to Zone N.5; the N.5/N.4 boundary was placed between Cores 43 and 44 , above the highest occurrence of Turborotalia kugleri in the upper part of 
TABLE 6

Distribution of Selected Neogene Planktonic Foraminifera at Site 237

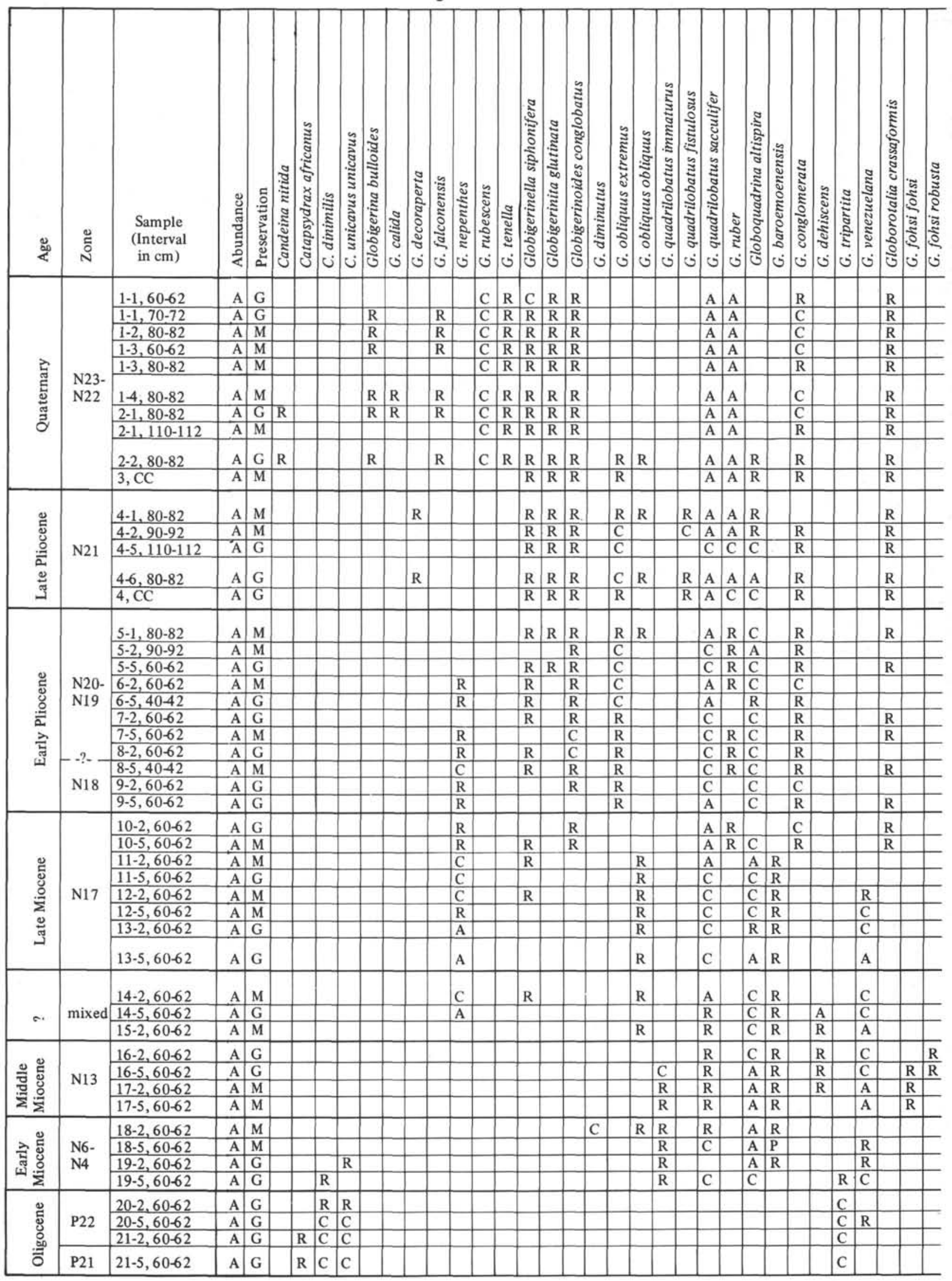


TABLE 6 - Continued

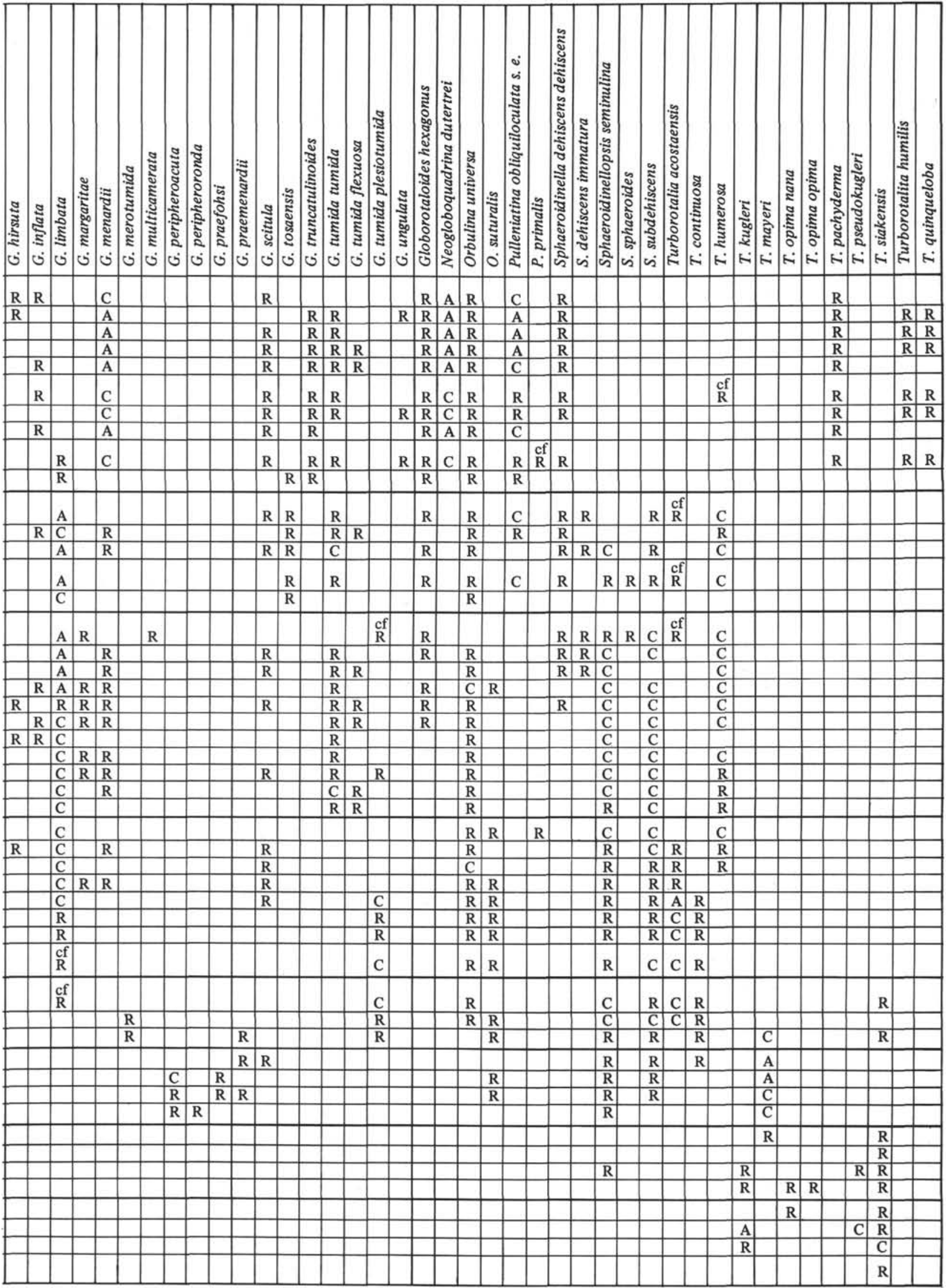


TABLE 7

Distribution of Selected Quaternary Planktonic Foraminifera at Site 238

\begin{tabular}{|c|c|c|c|c|c|c|c|c|c|c|c|c|c|c|c|c|c|c|c|c|c|c|c|c|c|c|c|c|c|c|c|c|c|c|}
\hline$\frac{\pi}{<}$ & స్ & $\begin{array}{c}\text { Sample } \\
\text { (Interval } \\
\text { in cm) }\end{array}$ & 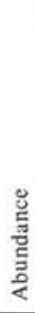 & 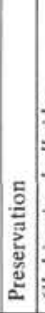 & 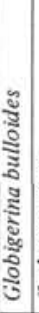 & 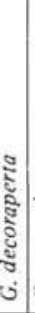 & 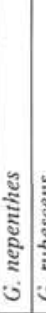 & 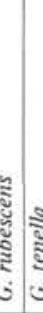 & 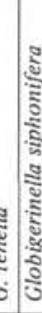 & 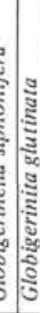 & 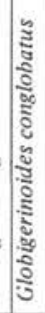 & 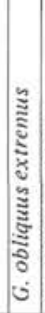 & 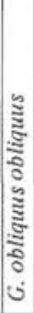 & 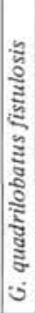 & 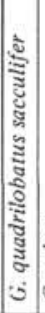 & 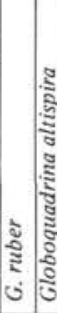 & 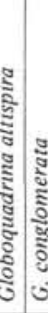 & 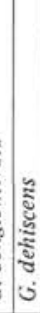 & 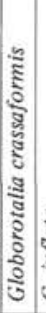 & 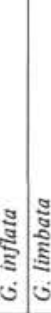 & 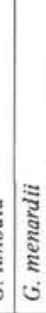 & 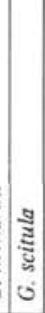 & : & 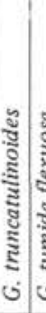 & 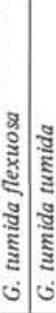 & 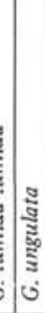 & 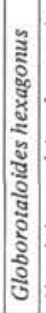 & 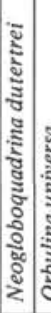 & 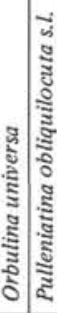 & 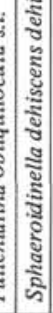 & 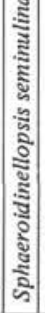 & 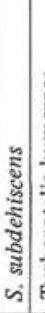 & & 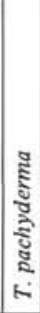 \\
\hline 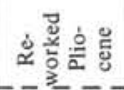 & 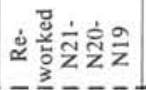 & $\begin{array}{l}1-1,70-72 \\
1-2,80-82 \\
1-3,80-82\end{array}$ & $\begin{array}{l}\mathrm{A} \\
\mathrm{A} \\
\mathrm{A}\end{array}$ & $\begin{array}{l}\mathrm{M} \\
\mathrm{M} \\
\mathrm{G} \\
\end{array}$ & & $\mathbf{R}$ & $\begin{array}{l}\mathrm{R} \\
\mathrm{R} \\
\mathrm{R}\end{array}$ & & $\begin{array}{l}\mathrm{R} \\
\mathrm{R} \\
\mathrm{R}\end{array}$ & $\begin{array}{l}R \\
R \\
R\end{array}$ & $\begin{array}{l}\text { C } \\
\text { C } \\
\text { C }\end{array}$ & $\mathrm{R}$ & $\mathrm{R}$ & $\begin{array}{l}\mathrm{R} \\
\mathrm{R} \\
\mathrm{R} \\
\end{array}$ & \begin{tabular}{|l}
$\mathrm{A}$ \\
$\mathrm{A}$ \\
$\mathrm{A}$
\end{tabular} & \begin{tabular}{l|l}
$\mathrm{C}$ & $\mathrm{C}$ \\
$\mathrm{C}$ & $\mathrm{C}$ \\
$\mathrm{C}$ & $\mathrm{C}$ \\
\end{tabular} & $\begin{array}{lll}C & R \\
C & R \\
C & R \\
\end{array}$ & $\begin{array}{l}R \\
R \\
R\end{array}$ & \begin{tabular}{|l|}
$\mathrm{R}$ \\
$\mathrm{R}$ \\
$\mathrm{R}$ \\
\end{tabular} & c & $\begin{array}{l}\text { C } \\
\text { C } \\
C\end{array}$ & $\begin{array}{l}\mathrm{R} \\
\mathrm{R} \\
\mathrm{R}\end{array}$ & \begin{tabular}{l|l}
$\mathrm{R}$ & \\
$\mathrm{R}$ & \\
$\mathrm{R}$ & \\
\end{tabular} & \begin{tabular}{l|l}
$\mathrm{R}$ & $\mathbf{1}$ \\
$\mathrm{R}$ & $\mathrm{K}$ \\
$\mathrm{R}$ & $\mathrm{F}$ \\
\end{tabular} & \begin{tabular}{l|l}
$R$ & $C$ \\
$R$ & $C$ \\
$R$ & $C$ \\
\end{tabular} & & \begin{tabular}{l|}
$\mathrm{R}$ \\
$\mathrm{R}$ \\
$\mathrm{R}$ \\
\end{tabular} & \begin{tabular}{l|l}
$\mathrm{c}$ & 1 \\
$\mathrm{C}$ & 1 \\
$\mathrm{C}$ & $\mathrm{H}$ \\
\end{tabular} & \begin{tabular}{l|l}
$\mathrm{R}$ & $\mathrm{A}$ \\
$\mathrm{R}$ & $\mathrm{A}$ \\
$\mathrm{R}$ & $\mathrm{A}$ \\
\end{tabular} & $\begin{array}{l}\mathrm{C} \\
\mathrm{C} \\
\mathrm{C}\end{array}$ & \begin{tabular}{|l|}
$\mathrm{R}$ \\
$\mathrm{R}$ \\
$\mathrm{R}$ \\
\end{tabular} & \begin{tabular}{l|l}
$\mathrm{R}$ & \\
$\mathrm{R}$ & \\
$\mathrm{R}$ & $\mathbf{1}$ \\
\end{tabular} & & \begin{tabular}{|l}
$\mathrm{R}$ \\
$\mathrm{R}$ \\
$\mathrm{R}$ \\
\end{tabular} \\
\hline 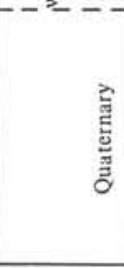 & 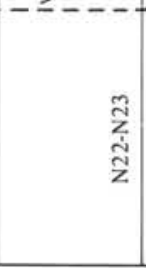 & $\begin{array}{l}2-1,85-87 \\
2-3,80-82 \\
2-4,100-102 \\
2-5,80-82 \\
3-1,80-82 \\
3-2,80-82 \\
3-3,80-82 \\
3-5,80-82 \\
3-6,80-82 \\
4-1,80-82 \\
\end{array}$ & $\begin{array}{ll}\mathrm{R} \\
\mathrm{A} \\
\mathrm{A} \\
\mathrm{A} \\
\mathrm{A} \\
\mathrm{A} \\
\mathrm{A} \\
\mathrm{A} \\
\mathrm{A} \\
\mathrm{A}\end{array}$ & \begin{tabular}{l|l|}
$M$ \\
$P$ \\
$M$ \\
$M$ \\
$M$ \\
$M$ \\
$M$ \\
$M$ \\
$G$ \\
$M$
\end{tabular} & $\begin{array}{l}R \\
R \\
R \\
R \\
R\end{array}$ & & 1 & \begin{tabular}{l|l}
$R$ & $R$ \\
$R$ & $R$ \\
$R$ & $R$ \\
$R$ & $R$ \\
$R$ & $R$
\end{tabular} & $\begin{array}{l}R \\
R \\
R \\
R \\
R \\
R \\
R \\
R \\
R \\
R \\
R \\
R\end{array}$ & $\begin{array}{l}\text { C } \\
C \\
C \\
C \\
C \\
C \\
C \\
C \\
C \\
C \\
C\end{array}$ & $\begin{array}{l}\mathrm{C} \\
\mathrm{C} \\
\mathrm{C} \\
\mathrm{C} \\
\mathrm{C} \\
\mathrm{C} \\
\mathrm{C} \\
\mathrm{C} \\
\mathrm{C} \\
\mathrm{C}\end{array}$ & & & $\mathrm{R}$ & \begin{tabular}{|l|}
$\mathrm{A}$ \\
$\mathrm{A}$ \\
$\mathrm{A}$ \\
$\mathrm{A}$ \\
$\mathrm{A}$ \\
$\mathrm{A}$ \\
$\mathrm{A}$ \\
$\mathrm{A}$ \\
$\mathrm{A}$ \\
$\mathrm{A}$
\end{tabular} & $\begin{array}{ll}\text { C } \\
\text { C } \\
\text { C } \\
\text { C } \\
\text { A } \\
\text { C } \\
\text { C } \\
\text { C } \\
\text { A } \\
\text { C } & \\
\end{array}$ & $\begin{array}{l}\mathrm{C} \\
\mathrm{C} \\
\mathrm{R} \\
\mathrm{C} \\
\mathrm{R}\end{array}$ & & \begin{tabular}{|l|l|}
$R$ & \\
$R$ & \\
$R$ & \\
$R$ & \\
$R$ & \\
$R$ & \\
$R$
\end{tabular} & $\mathrm{R}$ & $\begin{array}{l}\text { C } \\
\text { C } \\
\text { C } \\
\text { C } \\
\text { C } \\
\text { C } \\
\text { C } \\
\text { C } \\
\text { C } \\
\text { C }\end{array}$ & $\begin{array}{ll}R \\
R \\
R \\
R \\
R \\
R \\
R \\
R \\
R \\
R\end{array}$ & \begin{tabular}{l|l} 
& \\
$\mathrm{R}$ & $\mathrm{R}$ \\
$\mathrm{R}$ & \\
$\mathrm{R}$ &
\end{tabular} & \begin{tabular}{l|l}
$R$ & \\
$R$ & \\
$R$ & \\
$R$ & \\
$C$ & \\
$C$ & \\
$R$ &
\end{tabular} & \begin{tabular}{l|l}
$\mathrm{C}$ \\
$\mathrm{C}$ \\
$\mathrm{C}$ \\
$\mathrm{C}$ \\
$\mathrm{C}$ \\
$\mathrm{C}$ \\
$\mathrm{C}$ \\
$\mathrm{C}$ \\
$\mathrm{C}$ \\
$\mathrm{C}$
\end{tabular} & $\begin{array}{l}R \\
R \\
R\end{array}$ & \begin{tabular}{l|}
$R$ \\
$R$ \\
$R$ \\
$R$ \\
$R$ \\
$R$ \\
$R$ \\
$R$
\end{tabular} & 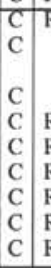 & \begin{tabular}{l|l}
$\mathrm{R}$ & $\mathrm{A}$ \\
$\mathrm{C}$ \\
$\mathrm{C}$ \\
& $\mathrm{C}$ \\
$\mathrm{R}$ & $\mathrm{C}$ \\
$\mathrm{R}$ & $\mathrm{C}$ \\
$\mathrm{R}$ & $\mathrm{C}$ \\
$\mathrm{R}$ & $\mathrm{C}$ \\
$\mathrm{R}$ & $\mathrm{C}$ \\
$\mathrm{R}$ & $\mathrm{C}$
\end{tabular} & \begin{tabular}{|l|}
$R$ \\
$R$ \\
$R$ \\
$R$ \\
$R$ \\
$R$ \\
$R$ \\
$R$ \\
$R$
\end{tabular} & \begin{tabular}{|l|} 
\\
\end{tabular} & & & $\mathbf{R}$ \\
\hline
\end{tabular}

TABLE 8

Distribution of Selected Early Neogene Planktonic Foraminifera at Site 238

\begin{tabular}{|c|c|c|c|c|c|c|c|c|c|c|c|c|c|c|c|c|c|c|c|c|c|c|c|c|c|c|c|c|c|c|c|c|c|c|c|}
\hline 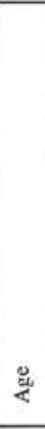 & : & & \begin{tabular}{|l} 
\\
\\
\end{tabular} & 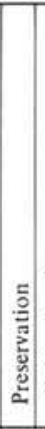 & 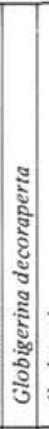 & $\begin{array}{l}\widetilde{3} \\
\mathbf{y} \\
\mathrm{v}\end{array}$ & 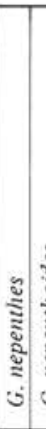 & 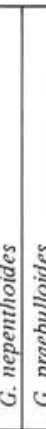 & 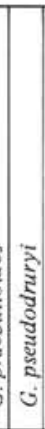 & \begin{tabular}{c}
. \\
\hdashline \\
$\vdots$ \\
$\vdots$ \\
$\vdots$ \\
\hdashline
\end{tabular} & 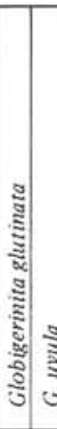 & 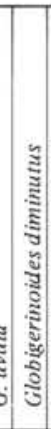 & 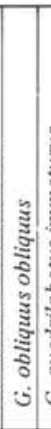 & 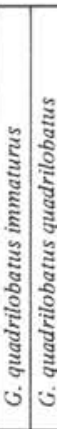 & 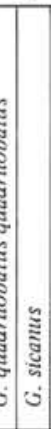 & 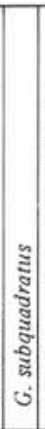 & 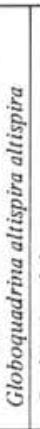 & 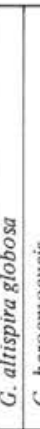 & ن & 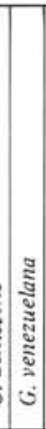 & 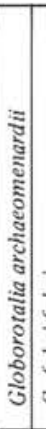 & ن) & 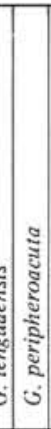 & 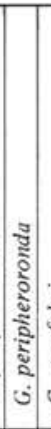 & (5) & 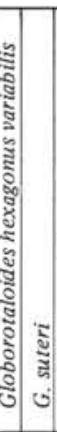 & 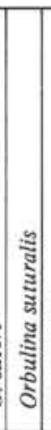 & : & 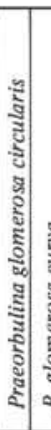 & 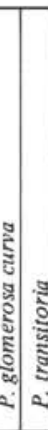 & 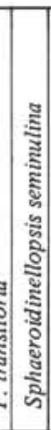 & 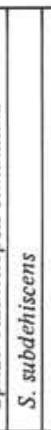 & 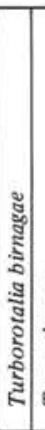 & . & 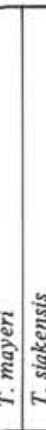 \\
\hline \multirow{9}{*}{ 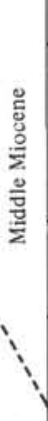 } & & $32-34$ & $\mathrm{C}$ & $\mathrm{M}$ & $\mathrm{R}$ & $\mathrm{R}$ & $\mathrm{R}$ & & & & $\mathrm{R}$ & & C & & & C & $\mathrm{C}$ & & $\mathrm{R}$ & C & & $\mathrm{R}$ & & & & & $\mathrm{R}$ & $\mathrm{R}$ & & & $\mathrm{R}$ & $\mathrm{R}$ & & C & $\begin{array}{ll}C \\
\end{array}$ \\
\hline & \multirow{4}{*}{$\mathrm{N} 13$} & $33-1,100-102$ & C & $\mathrm{M}$ & $\mathrm{R}$ & R & & & & $\mathrm{R}$ & $\mathrm{R}$ & & 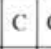 & c & & c & c & & $\mathbf{R}$ & C & & $\mathrm{R}$ & $R$ & & $\mathrm{R}$ & & $\mathrm{R}$ & R & & & $\mathrm{R}$ & $\mathrm{R}$ & & c & $\begin{array}{ll}c & R \\
\end{array}$ \\
\hline & & $34-2,60-62$ & C & G & $\mathrm{R}$ & & & & & & \multicolumn{5}{|c|}{ minute fauna } & & & & & & & & & & & & & & & & & & & $\mathrm{R}$ & \\
\hline & & $34-4,27-29$ & c & $\mathrm{M}$ & $\mathrm{R}$ & $R$ & & & & $\mathrm{R}$ & $\mathrm{R}$ & & c & c & & c & c & $\mathrm{R}$ & $\mathrm{R}$ & $\mathrm{c}$ & & $\mathrm{R}$ & & & F & & $\mathrm{R}$ & $\mathrm{R}$ & & & $\mathrm{R}$ & $\mathrm{R}$ & & C & \begin{tabular}{|l|l|}
$\mathrm{C}$ & $\mathrm{R}$ \\
\end{tabular} \\
\hline & & \begin{tabular}{|l|}
$35-5,70-72$ \\
\end{tabular} & C & G & $\mathrm{R}$ & C & & & & $\mathrm{R}$ & $\mathrm{R}$ & & C & C & & C & C & & \begin{tabular}{l|l}
$\mathrm{R}$ & $\mathrm{R}$ \\
\end{tabular} & $R$ & & C & $\mathrm{R}$ & & \begin{tabular}{l|l}
$R$ & $B$ \\
\end{tabular} & & $\mathrm{R}$ & & & & $\mathrm{R}$ & $\mathrm{R}$ & & c & \\
\hline & \multirow[b]{2}{*}{ N10 } & $36-2,70-72$ & c & $\mathrm{P}$ & & & & & & c & $\mathrm{R}$ & & c & C & & $R$ & C & & $\mathbf{R}$ & $R$ & $\begin{array}{l}\mathrm{cf} \\
\mathrm{R} \\
\end{array}$ & & c & & & & & & & & $\mathrm{R}$ & & & & C \\
\hline & & $0-22$ & $\mathrm{C}$ & $\mathrm{M}$ & & & & & & c & $\mathrm{C}$ & & c: 1 & $\mathrm{R}$ & $\begin{array}{l}\mathrm{ct} \\
\mathrm{R} \\
\end{array}$ & & C & & \begin{tabular}{l|l}
$R$ & $R$ \\
\end{tabular} & $R$ & & & C & $\mathrm{R}$ & & & & $\mathrm{R}$ & & & $\mathrm{C}$ & & & & $\mathrm{C}$ C \\
\hline & & $37-2,120-122$ & c & $M$ & & & & R & & c & $\mathrm{c}$ & & & $\mathrm{R}$ & $R$ & $R$ & C & $\mathrm{R}$ & \begin{tabular}{l|l}
$R$ & $R$ \\
\end{tabular} & & $\mathrm{k}$ & & & $\mathrm{k}$ & & & & & \begin{tabular}{l|l}
$R$ & $B$ \\
\end{tabular} & $\underline{\mathbf{R}}$ & & & & R & $R$ \\
\hline & & $37-5,80-82$ & C & $\mathrm{M}$ & & & & R & $\mathrm{R}$ & C & C & & $\mathrm{R}$ & $\mathrm{R}$ & $\begin{array}{ll}c f \\
\text { R } \\
\end{array}$ & & C & & $\begin{array}{ll}\mathrm{c} & \mathrm{C} \\
\end{array}$ & $R$ & $\mathrm{R}$ & & & $R$ & & & & $\mathrm{R}$ & & & $\mathrm{R}$ & & & $\begin{array}{lll}R & R \\
\end{array}$ & $\mathrm{R}$ \\
\hline \multirow{4}{*}{ 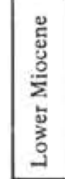 } & \multirow{4}{*}{ N8 } & $38-5,70-72$ & c & M & & & & $\mathrm{R}$ & & c & $\mathrm{C}$ & $\mathrm{R}$ & $\mathrm{R}$ & $\mathrm{R}$ & $R$ & c & C & $\mathrm{R}$ & c $\mathrm{C}$ & $R$ & $\mathrm{R}$ & & & C & & $R$ & & & & $\mathrm{R}$ & $R$ & & $\mathrm{~K}$ & R & $\begin{array}{ll}\mathrm{R} & \mathrm{R} \\
\end{array}$ \\
\hline & & \begin{tabular}{|l}
$39-2,80-82$ \\
\end{tabular} & C & $\mathrm{M}$ & & & & C & $R$ & $R$ & & C & & & $R$ & C & C & & \begin{tabular}{l|l}
$c$ & C
\end{tabular} & & & & & & & $\mathrm{R}$ & & & R & R & & & R & & $\begin{array}{ll}R & R \\
\end{array}$ \\
\hline & & $40-2,50-52$ & C & $M$ & & & ( & $\begin{array}{ll}C & R \\
\end{array}$ & C & C & c & & $R$ & $\mathbf{R}$ & $\mathrm{C}$ & C & C & 4 & 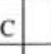 & & & & & & & 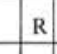 & & & & & & & - & & \\
\hline & & $41-2,70-72$ & c & $\mathrm{M}$ & & & & C & $\mathrm{C}$ & $\mathrm{R}$ & \begin{tabular}{l|l}
$\mathrm{C}$ & $\mathrm{C}$ \\
\end{tabular} & $R$ & \begin{tabular}{|l}
$\mathrm{cf}$ \\
$\mathrm{R}$ \\
\end{tabular} & $\mathrm{R}$ & R & C & C & & c & & & & & & & $\mathrm{R}$ & & & & $\mathrm{R}$ & & & 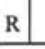 & & $\mathrm{k}$ \\
\hline
\end{tabular}


Core 44. The interval from Core 44 to Core 47 , Section 1 was assigned to Zone N.4, and the Oligocene/Miocene boundary (N.4/P.22) appears to lie between Core 47, Section 1 and Core 47, Section 3 at the lowest occurrence of Globigerinoides quadrilobatus primordius.

\section{REMARKS ON SELECTED BIOSTRATIGRAPHIC BOUNDARIES AND PLANKTONIC FORAMINIFERAL EVENTS}

One of the criteria defining the Pliocene/Pleistocene boundary is the extinction level of Discoaster (Ericson et al., 1963; Berggren et al., 1967; Hays and Berggren, 1971), an event closely associated with the Olduvai normal paleomagnetic event (= Gilsa event of Cox, 1969), approximately 1.8 m.y. B.P. (Berggren et al., 1967; Glass et al., 1967; Hays et al., 1969). The evolution of Globorotalia truncatulinoides from its ancestor G. tosaensis (N.22/N.21 zonal boundary) has been shown to correlate with this level (Berggren et al., 1967) and has also been used to determine the Pliocene/Pleistocene boundary (Banner and Blow, 1965; Hays and Berggren, 1971). Although the Globorotalia truncatulinoides evolutionary appearance may be a questionable datum as it has been suggested that the earliest appearance of this species is not simultaneous in various water masses (Kaneps, 1970, 1973; Kennett, 1973; Kennett and Gietzenauer, 1969; Theyer, 1973), the first occurrence of this species has often been found associated with the extinction level of Discoaster in tropical deep-sea sediments. The highest occurrence of Discoaster, however, and lowest occurrence of $G$. truncatulinoides may not always occur at the same level. Hays et al. (1969) have shown that in tropical Pacific cores $G$. truncatulinoides first appears above the extinction level of Discoaster.

These discrepancies may result, in part, from different interpretations of the "first appearance" of G. truncatulinoides. Some workers have placed this event at the first common occurrence of this species, and others at the first appearance of isolated specimens. At the central western Indian Ocean sites of Leg 24, where the sedimentation rate is slow, $G$. truncatulinoides is common at the horizon of its first appearance. At the Gulf of Aden sites, in contrast, where rapid sedimentation has produced an expanded stratigraphic section this species occurs as rare and isolated specimens for up to 60 meters below the level at which it becomes common. The N.22/N.21 boundary has been placed, in the Gulf of Aden, at the earliest common occurrence of $G$. truncatulinoides. This horizon proved easy to recognize and correlate within this basin, although occasional specimens with a fully developed imperforate keel occur sporadically below this level. The zonal boundary as so defined, however, is younger than the extinction level of Discoaster brouweri, which was used in this volume as a basis for placing the Pliocene/Pleistocene boundary.

The oldest occurrence of Globigerina tenella was usually found to be contemporaneous with the base of common $G$. truncatulinoides. Other foraminiferal events, such as the youngest occurrences of Globigerina decoraperta, Globigerinoides obliquus s.1., G. quadrilobatus fistulosus, and Globorotalia limbata, all of which have been shown to approximate the N.22/N.21 boundary (Parker, 1973; Briskin and
Berggren, in press; Fleisher, 1974) occurred near the boundary as recognized in the present study. In the Gulf of Aden these events are either contemporaneous with the lowest common occurrence of $G$. truncatulinoides or slightly older, but the order in which they occur is not consistent. The most reliable of these events appears to be the extinction level of Globorotalia limbata. This species is common in Pliocene and Miocene assemblages at all Leg 24 sites, and its highest occurrence is also marked by the highest occurrence of Discoaster brouweri. The extinction horizon of Globorotalia limbata is also marked in the Gulf of Aden by the sole occurrence of Globoquadrina sp. A, a form morphologically intermediate between Globoquadrina and Pulleniatina. This morphotype may be an abnormal form developed in response to unfavorable oceanographic conditions at the onset of the Pleistocene cooling. At the three Gulf of Aden sites, a horizon with dextrally coiled Globorotalia tumida was found between the base of the common occurrence of $G$. truncatulinoides and the top of G. limbata, an event also recognized near the Pliocene/ Pleistocene boundary in equatorial Pacific cores by Kierstead et al. (1969).

This succession of events in the sedimentary sequences of the Gulf of Aden permits correlation between the three sites (Figure 2). Further study of these expanded section with closely spaced sampling intervals may provide more detailed information on faunal modifications associated with the Pliocene/Pleistocene boundary. The central western Indian Ocean sites, in contrast, are not well suited for stratigraphic investigation of this sort because intervals of no recovery (at Sites 236 and 237), or of displaced lower Pliocene sediments (at Site 238) occur near the boundary.

The N.21/N.20-N.19 zonal limit, which approximates the late/early Pliocene boundary, is defined by the evolutionary appearance of Globorotalia tosaensis. In several instances, because of the rarity of this species, it was found more reliable to use the extinction level of Globoquadrina altispira and Sphaeroidinellopsis spp. to mark the top of Zone N.20-N.19. These species, common components of the Leg 24 Miocene and lower Pliocene assemblages, are known to have become extinct shortly after the evolution of G. tosaensis (Berggren, 1973a).

Several foraminiferal events are known to occur within the early Pliocene. The extinction of Globorotalia margaritae and Globigerina nepenthes and the evolution of Sphaeroidinella dehiscens s.l. (which defines the N.19/N.18 boundary) occurred at approximately $3.4,3.7$, and 4.7 m.y. B.P. (Berggren, 1973a). These species are of little value for Pliocene correlations in the western Indian Ocean because they are rare and because the sequence of events discussed above proved inconsistent. The scarcity of $G$. margaritae at all sites makes it an unreliable stratigraphic indicator for this region and dissolution probably strongly affected the observed range of $G$. nepenthes in the Gulf of Aden. The lowest specimens of Sphaeroidinella dehiscens s.l. were usually observed stratigraphically higher than its known evolutionary appearance, a discrepancy also noted in the neighboring Arabian Sea (Fleisher, 1974). A delayed first appearance of Sphaeroidinella dehiscens relative to other paleontological events has been reported in other areas as 


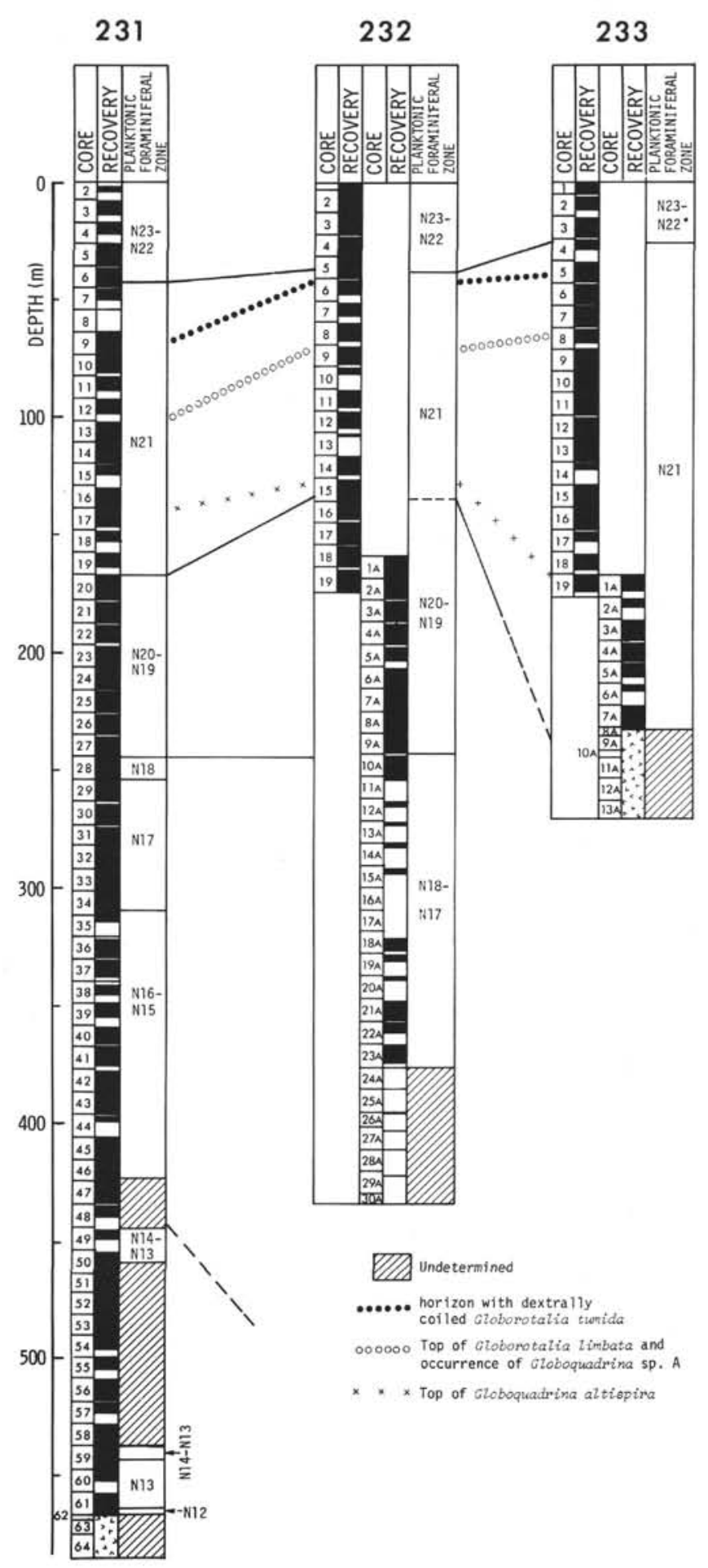

Figure 2. Correlation and distribution of planktonic foraminiferal zones in DSDP Sites in the Gulf of Aden. 


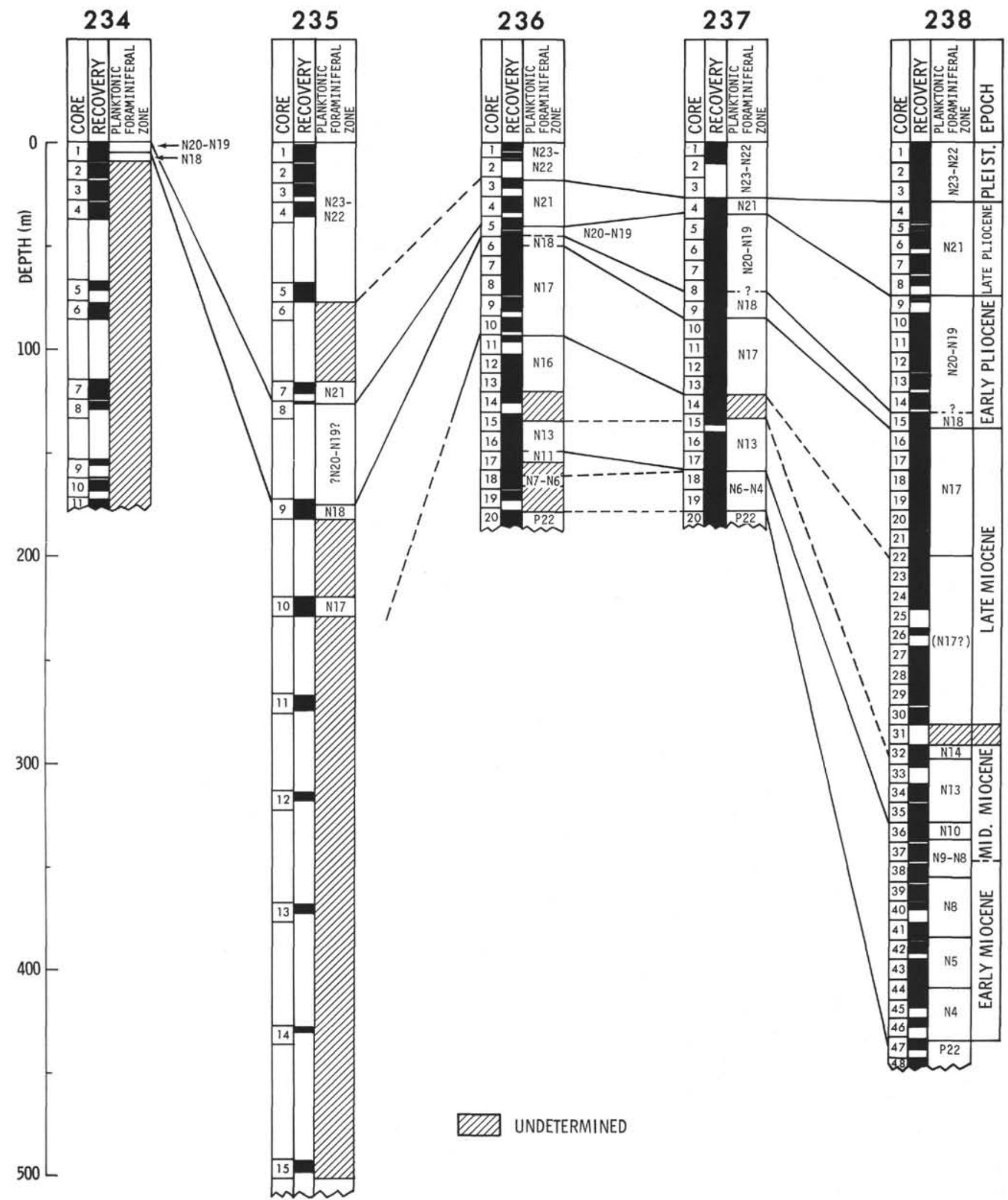

Figure 3. Correlation and distribution of planktonic foraminiferal zones in DSDP Leg 24 Sites in the Somali Basin and central western Indian Ocean. 
well (Bandy, 1973; Kennett, 1973). Although taxonomic problems may be involved in the recognition of $S$. dehiscens immatura, as pointed out by Brönnimann and Resig (1971), the first appearance of $S$. dehiscens s.l. appears to fluctuate sufficiently to preclude its use as a reliable datum.

The Miocene/Pliocene boundary (N.18/N.17) is well marked at most sites by the lowest occurrence of Globorotalia tumida tumida and Ceratolithus acutus. The latter nannofossil species is known to appear at approximately 4.9 m.y. B.P. in the lowermost interval of the Gilbert paleomagnetic epoch (Gartner, 1973), a level correlative with the Miocene/Pliocene boundary in the Mediterranean (Berggren, 1973b). At Site 232, however, forms intermediate between Globorotalia tumida tumida and its ancestor $G$. tumida plesiotumida, occur commonly throughout the lower 30 meters of the section. The N.18/N.17 zonal boundary could not be identified here, although the Miocene/Pliocene boundary was recognized in this interval on the basis of nannofossils and radiolarian events.

Distinction of the late Miocene zone boundaries (N.17/N.16 and N.16/N.15) proved difficult because of problems encountered in distinguishing elements of the Globorotalia merotumida- $G$. tumida plesiotumida lineage. Although typical populations of $G$. tumida plesiotumida were common at several sites, the broad range of variations in this species precluded the recognition of a compelling initial appearance datum. Zonal assignments were further complicated by common reworking of older sediments into the lower part of upper Miocene sequences.

An interval of upper and middle Miocene mixed faunas was found at all central western Indian Ocean sites. It cannot be determined whether an unconformity occurs at this level or whether the mixed faunas represent a condensed lowermost upper Miocene and uppermost middle Miocene interval. An increase in bottom water circulation may have been responsible for a period of nondeposition or of reworking of older faunas into younger sediments in the whole western Indian Ocean. Similar redeposition was noted abouve an N.17/N.10 unconformity in the adjacent Arabian Sea (Fleisher, 1974). Unfortunately, the succession of paleontological events in this part of the stratigraphic column could not be fully determined in the expanded Neogene section at Site 231 in the Gulf of Aden, where inadequate preservation of planktonic foraminifera precluded conclusive biostratigraphic interpretations.

The base of Zone N.13 below the mixed interval is clearly marked by the base of Sphaeroidinellopsis subdehiscens. Below this level the lower middle Miocene and lower Miocene sections are very condensed. Mixed faunas are common and signs of significant dissolution are frequent. The sedimentation rate for this interval is very low, averaging about $2 \mathrm{~m} / \mathrm{m} . \mathrm{y}$. at Sites 236 and 237 and 5 $\mathrm{m} / \mathrm{m} . \mathrm{y}$. at Site 238 . These considerations and the short time spans of many of the early Neogene zones precluded a detailed biostratigraphic investigation of this interval. Study of more closely spaced samples may resolve these problems.

\section{ACKNOWLEDGMENTS}

The authors have benefited in the preparation of this report from valuable discussions with the late O. L. Bandy and R. L. Fleisher (University of Southern California).
This study was supported under Oceanographic Section, National Foundation NSF Grant GA-34145 and represents Contribution No. 349, Department of Geological Sciences, University of Southern California.

\section{REFERENCES}

Bandy, O. L., 1973. Chronology and paleoenvironmental trends, late Miocene-early Pliocene, western Mediterranean. In Messinian events in the Mediterranean, C. W. Drooger (Ed.), Koninklijke Nederlandse Akademie Van Wetenschappen, Amsterdam, p. 21-25.

Banner, F. T. and Blow, W. H., 1965. Progress in the planktonic foraminiferal biostratigraphy of the Neogene: Nature, v. 208, p. 1164-1166.

Berggren, W. A., 1973a. The Pliocene time scale: calibration of planktonic foraminiferal and calcareous nannoplankton zones: Nature, v. 243, p. 391-397.

Berggren, W. A., 1973 b. Biostratigraphy and biochronology of the Late Miocene (Tortonian and Messinian) of the Mediterranean. In Messinian events in the Mediterranean. C. W. Drooger (Ed.), Koninklijke Nederlandse Akademie Van Wetenschappen, Amsterdam, p. 10-20.

Berggren, W. A., Phillips, J. D., Bertels, A., and Wall, D., 1967. Late Pliocene-Pleistocene stratigraphy in deep-sea cores from the south central North Atlantic: Nature, v. 216 , p. 253-254.

Berggren W. A. and Van Couvering, J., 1974. Biostratigraphy, geochronology and paleoclimatology of the last 15 million years in marine and continental sequences; Palaeogeo., Palaeoclim., Palaeoecol., in press.

Bolli, H. M., 1957. Planktonic foraminifera from the Oligocene-Miocene Cipero and Lengua formations of Trinidad, B. W. I.: U. S. Nat. Museum Bull. 215, p. 97-124.

1966. Zonation of Cretaceous to Pliocene marine sediments based on planktonic foraminifers: Bol. Inform., Asoc. Venez. Geol., Min., Petrol., v. 9, p. 3-32.

Blow, W. H., 1969. Late middle Eocene to Recent planktonic foraminiferal biostratigraphy: Int. Conf. Plankt. Microfossils, 1st, Proc., Brönnimann, P. and Renz, H. H. (Eds.), Leiden (Brill), v. 1, p. 199-422.

Briskin, M. and Berggren, W. A., in press. Pleistocene stratigraphy and quantitative paleooceanography of tropical North Atlantic Core V16-205.

Brönnimann, P. and Resig, J., 1971. A Neogene globigerinacean biochronologic time-scale of the Southwestern Pacific. In Winterer, E. L. et al., Initial Reports of the Deep Sea Drilling Project, Volume 7; Washington (U.S. Government Printing Office), p. 1235-1469.

Bunce, E. T., Langseth, M. G., Chase, R. L., and Ewing, M., 1967. Structure of the western Somali Basin; J. Geophys. Res., v. 72 , p. $2547-2555$.

Cox, A., 1969. Geomagnetic reversals: Science, v. 163, p. 237-245.

Ericson, D. B., Ewing, M., and Wollin, G., 1963. Pliocene-Pleistocene boundary in deep-sea sediments: Science, v. 139, p. 727-737.

Fleisher, R. L., 1974. Cenozoic planktonic foraminifera and biostratigraphy, Arabian Sea, Deep Sea Drilling Project, Leg 23A. In Whitmarsh, R. B., Weser, O. E., Ross, D. A., et al., Initial Reports of the Deep Sea Drilling Project, Volume 23: Washington (U.S. Government Printing Office), p. 1001-1072.

Gartner, S., 1973. Absolute chronology of the Late Neogene calcareous nannofossil succession in the 
Equatorial Pacific: Geol. Soc. Am. Bull., v. 84, p. 2021-2034.

Glass, B., Ericson, D. B., Heezen, B. C., Opdyke, N. D., and Glass, J. A., 1967. Geomagnetic reversals and Pleistocene chronology: Nature, v. 216, p. 437-442.

Hays, J. D. and Berggren, W.H., 1971. Quaternary Boundaries. In Funnell, B. M. and Riedel, W. R. (Eds.), Micropaleontology of oceans: Cambridge (Cambridge Univ. Press).

Hays, J. D., Saito, T., Opdyke, N. D., and Burckle, L. H., 1969. Pliocene-Pleistocene sediments of the equatorial Pacific: their paleomagnetic, biostratigraphic, and climatic record: Geol. Soc. Am. Bull., v. 80, p. 1481.

Kaneps, A. G., 1970. Late Neogene biostratigraphy (planktonic foraminifera), biogeography, and depositional history. PhD thesis, Columbia University, New York.

1973. Cenozoic planktonic foraminifera from the eastern equatorial Pacific Ocean. In van Andel, T. H., Heath, G. R., et al., Initial Reports of the Deep Sea Drilling Project, Volume 16: Washington (U.S. Government Printing Office), p. 713-746.

Kennett, J. P., 1973. Middle and Late Cenozoic planktonic foraminiferal biostratigraphy of the southwest PacificDSDP Leg 21. In Burns, R. E., Andrews, J. E., et al.,
Initial Reports of the Deep Sea Drilling Project, Volume 21: Washington (U.S. Government Printing Office), p. 575-640.

Kennett, J.P. and Geitzenauer, K. R., 1969. The Pliocene-Pleistocene boundary in a South Pacific deep-sea core: Nature, v. 224, p. 899.

Kierstead, C. H., Leidy, R. D., Fleisher, R. L. and Boersma, A., 1969. Neogene zonation of tropical cores. In Microfossils, 1st, Proc.: Int. Conf. Plank. Bronniman, P., and Renz, H. H. (Eds.); Leiden (Brill), v. 2, p. 328-338.

Laughton, A. S., Whitmarsh, R. B., and Jones, M. T., 1970. The evolution of the Gulf of Aden: Phil. Trans. Roy. Soc. London, Series A, v. 267, p. 227-266.

Matthews, D. H., Williams, C. A., and Laughton, A. S., 1967. Mid-ocean ridge in the mouth of the Gulf of Aden: Nature, v. 215, p. 1052-1053.

Parker, F.L., 1973. Late Cenozoic biostratigraphy (planktonic foraminifera) of tropical Atlantic deep-sea sections: Rev. Española Micropaleontol., v. 5, p. 253-289.

Ramsay, A. T. A. and Funnell, B. M., 1969. Upper Tertiary microfossils from the Alula-Fartak Trench, Gulf of Aden: Deep-Sea Res., v. 16, p. 25-43.

Theyer, F., 1973. Globorotalia truncatulinoides Datum Plan: evidence for a Gauss (Pliocene) age in subantarctic cores: Nature Phys. Sci., v. 241, p. 142-145. 


\section{PLATE 1}

Figures 1-3 Globorotalia menardii (Parker, Jones, and Brady). Sample 231-1-1, 130-132 cm.

1. Umbilical view, $\times 61$.

2. Spiral view, $\times 61$.

3. Side view, $\times 65$.

Figures 4, 5 Globorotalia cf. menardii (Parker, Jones, and Brady). Sample 231-16-2, 130-132 cm.

4. Umbilical view, $\times 59$.

5. Side view, $\times 59$.

Figures 6-8 Globorotalia limbata (d'Orbigny). Sample 231-13, CC.

6. Umbilical view, $\times 85$.

7. Spiral view, $\times 73$.

Figure 9 Globorotalia tumida tumida (Brady). Sample 231-3-4, 49-51 cm. Umbilical view, $\times 90$.

Figure $10 \quad$ Globorotalia tumida flexuosa (Koch). Sample 237. $1-1,70-72 \mathrm{~cm}$. Umbilical view, $X 59$.

Figures 11-13 Globorotalia tumida plesiotumida Blow and Banner. Sample 237-10-6, 80-82 cm.

11. Umbilical view, $\times 100$.

12. Spiral view, $\times 100$.

13. Side view, $X 110$.

Figures 14-16 Form intermediate between Globorotalia tumida plesiotumida Blow and Banner and Globorotalia tumida tumida (Brady). Sample 232A-22-2, 80-82 $\mathrm{cm}$.

14. Umbilical view, $\times 100$.

15. Spiral view, $X 100$.

16. Side view, $\times 100$. 


\section{PLATE 1}
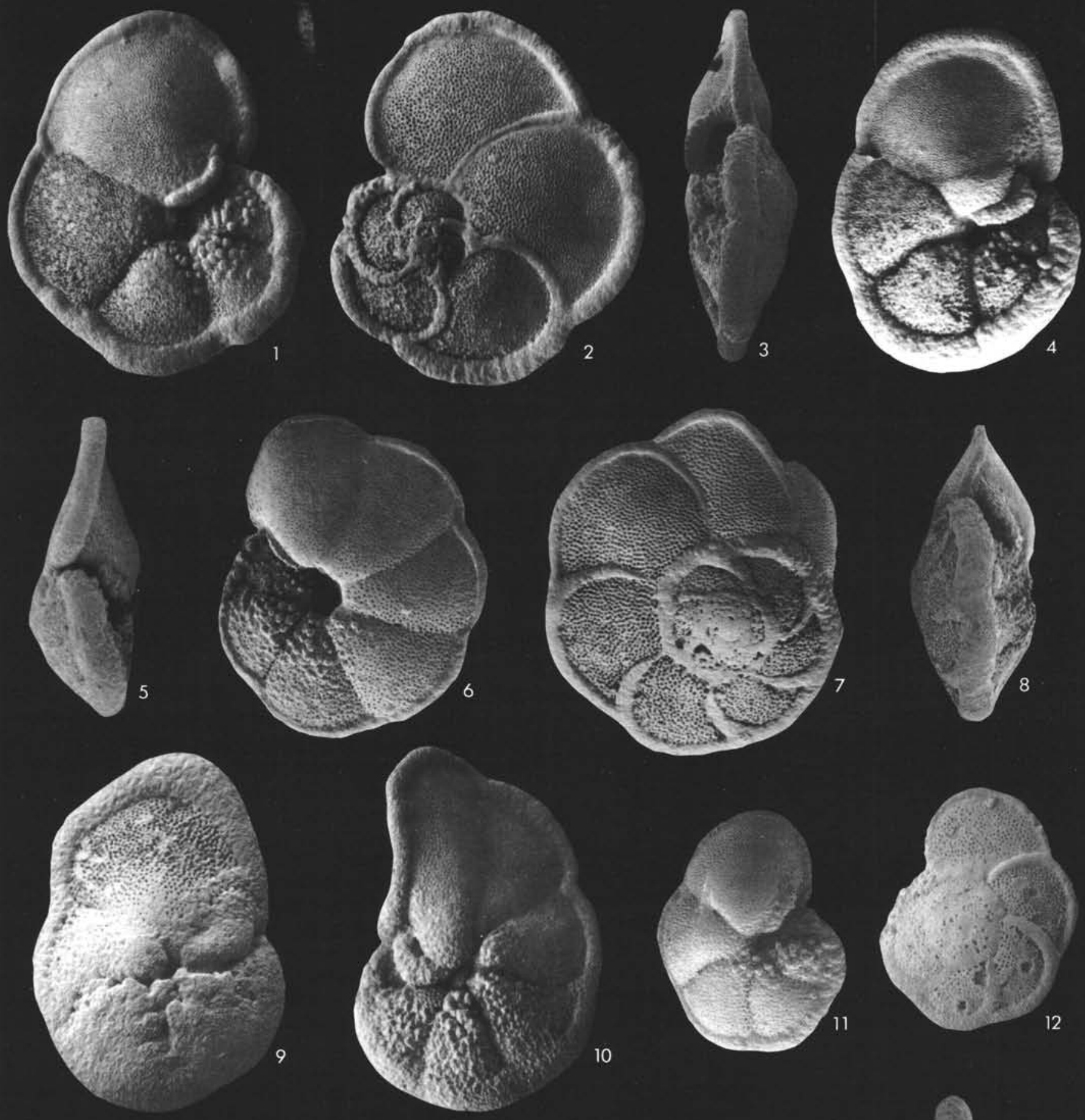

10
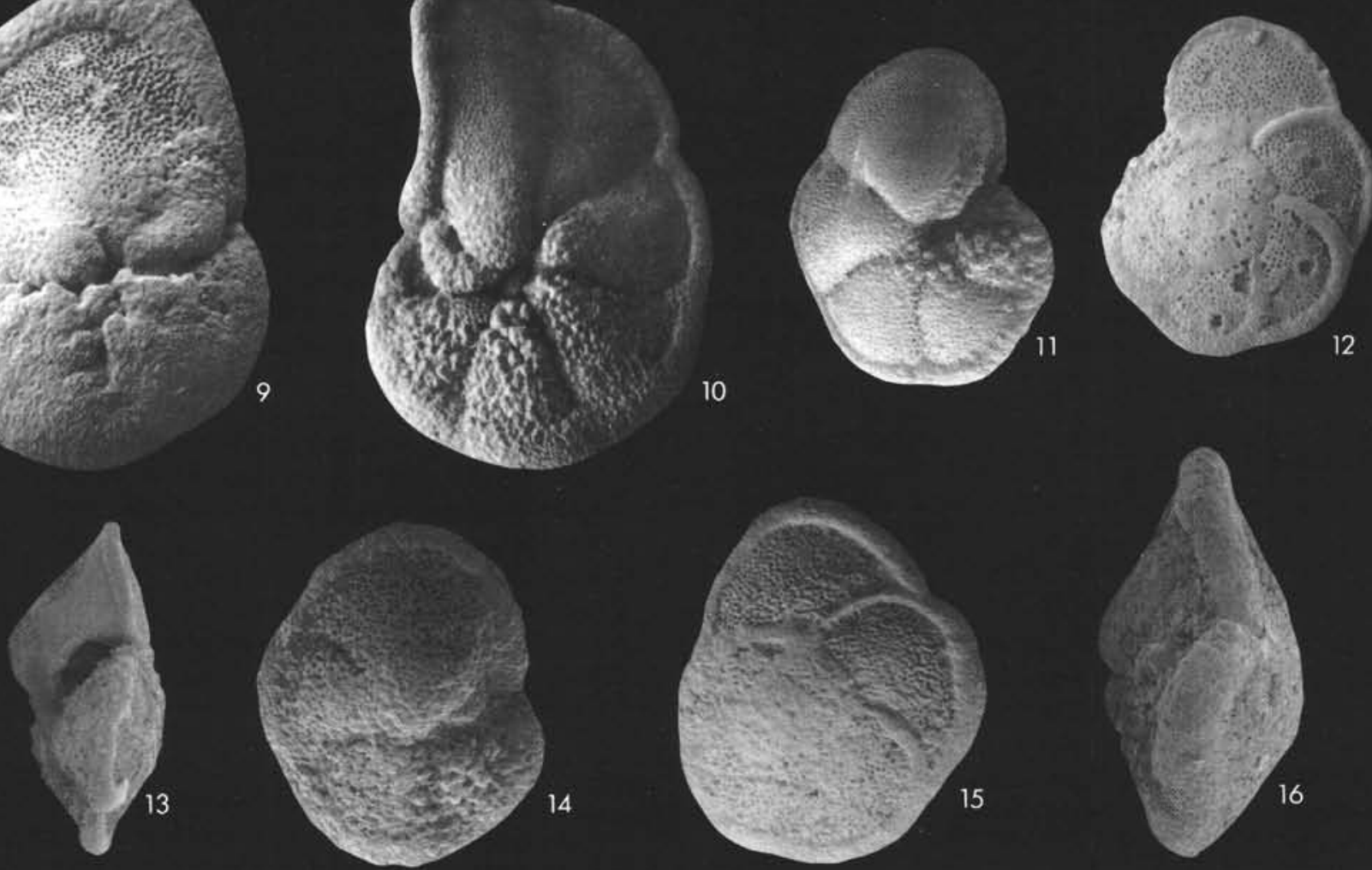


\section{PLATE 2}

Figures 1-3 Globorotalia cf. limbata (d'Orbigny). Sample 237. $13-6,80-82 \mathrm{~cm}$.

1. Umbilical view, $\times 98$.

2. Spiral view, $\times 96$.

3. Side view, $X 113$.

Figures 4-7 Globorotalia tosaensis Takayanagi and Saito.

4. Umbilical view, $X 117$. Sample $231-8, C C$.

5. Side view, $X 95$. Sample $231-9-3,70-72 \mathrm{~cm}$.

6. Oblique view, X96. Sample 231-8, CC.

7. Detail of Figure 6 showing the rounded edge with gradation between porous to nonporous areas. X333.

Figures 8-10 Globoquadrina sp. A. Sample 231-12, CC.

8. Umbilical view, $\times 98$.

9. Spiral view, $\times 96$.

10. Side view, $X 97$.

Figures 11-13 Globorotalia sp. A. Sample 231-60-2, 113-115 cm.

11. Umbilical view, $\times 133$

12. Spiral view, $X 133$.

13. Side view, $X 133$. 


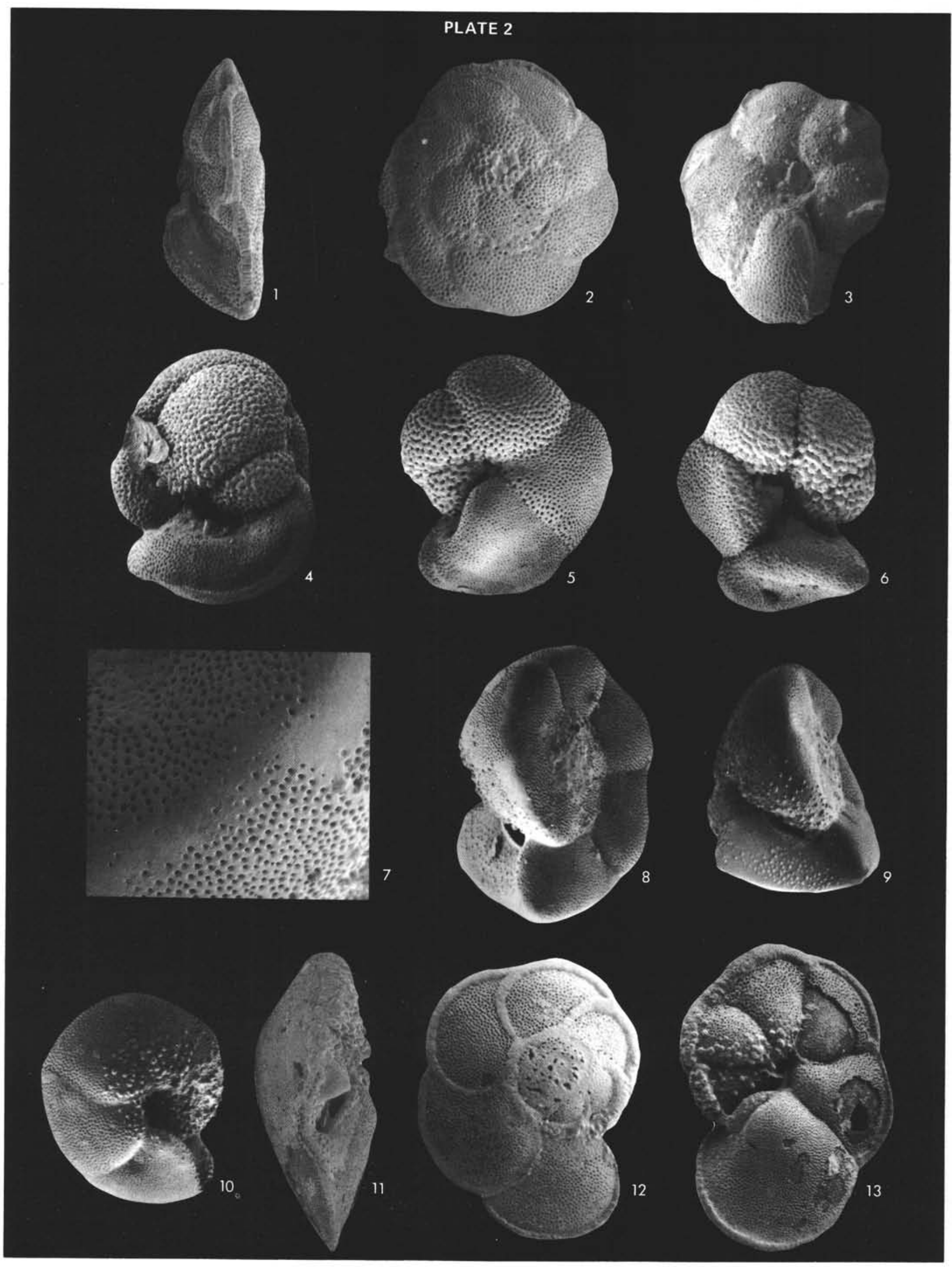

